\title{
A review of piling industry practices in Dubai, UAE: proposed UCS-based correlations
}

Benoît Latapie MSc, Eurlng

Technical Manager, Ground Engineering, WS Atkins \& Partners Overseas, Dubai, UAE (corresponding author: benoit.latapie@gmail.com)

Rhea A. Albelda MSc

Senior Geotechnical Engineer, Ground Engineering, WS Atkins \& Partners Overseas, Dubai, UAE

Michelle Abou Samra MSc

Graduate Geotechnical Engineer, Ground Engineering, WS Atkins \&

Partners Overseas, Dubai, UAE
Marwan Alzaylaie MSc

Senior Manager, Geotechnical Design, Dubai Creative Clusters Authority, Dubai, UAE

Joyshwin Sumputh BEng

Service Line Manager, Deep Foundation Testing, Fugro Mauritius, Quatre Bornes, Mauritius, Dubai, UAE

There is limited published information available on design guidance and performance of deep pile foundations in Dubai, UAE. In response to this situation, the piling industry tends to be over-conservative when designing foundation systems for buildings and infrastructure. Consultants, pile testing experts and the Dubai Creative Clusters Authority decided to collaborate with a common goal: share information with the industry and make pile design recommendations to help colleagues prevent the large-scale over-engineering of pile foundations currently ongoing in the Emirate of Dubai. A total of over 200 pile load test results, from which 91 are preliminary pile load tests, were available to the authors to conduct the study presented in this paper. The interpretation of the available information combined with finite-element back-analyses enabled the authors to propose Dubai-specific relationships between the rock's unconfined compressive strength and the pile's ultimate skin friction resistance. Relationships between the rock's unconfined compressive strength and its elastic modulus are also proposed.

\section{Notation}

$c^{\prime} \quad$ cohesion

E rock mass stiffness

$k_{0} \quad$ coefficient of at-rest earth pressures

$\alpha \quad$ side resistance factor

$\beta \quad$ side resistance factor

$\gamma \quad$ density

$\sigma_{3 \max }^{\prime}$ maximum confining pressure

$\sigma_{\mathrm{cm}}^{\prime} \quad$ global rock mass strength

$\sigma_{\mathrm{ci}} \quad$ unconfined compressive strength

$\tau_{\mathrm{m}} \quad$ measured skin friction

$\tau_{\mathrm{PTP}} \quad$ skin friction assumed in PTP design

$\tau_{\text {ult }} \quad$ ultimate skin friction

$\phi^{\prime} \quad$ angle of internal friction

\section{Introduction}

There is limited published information available on design guidance and performance of deep pile foundations in Dubai, UAE. A few case studies of prestigious projects are available, but these are focused on the design procedure rather than the optimisation of pile foundation designs. This is not representative of the size and experience of the local piling industry nor the vast amount of nonpublished information available. The goal of this paper is to share information with the industry and make pile design recommendations to help colleagues prevent the large-scale over-engineering of pile foundations currently ongoing in the Emirate of Dubai. To protect the confidentiality of the project information that this paper relies on, details enabling the identification of such projects are not shared. A sufficiently large and geographically dispersed database was selected to ensure that project-specific knowledge does not affect the conclusions and recommendations drawn in this paper and their validity across Dubai.

A database of pile load tests was compiled from past projects and used to support back-analyses using the finite-element method. A rigorous and systematic process was used for each data set to estimate each pile load test skin friction ultimate capacity. The results were used to propose suitable correlations between laboratory unconfined compressive strength (UCS) test results of rock samples and ultimate skin friction resistance of pile foundations for the Emirate of Dubai, from both measured and back-analysed values.

\section{Dubai: the local context and practices}

The piling industry and established design practices

Construction of high-rise towers (i.e. over $100 \mathrm{~m}$ high) and large structures is a booming industry in Dubai since the beginning of the century, as illustrated in Figure 1. Architecture concepts are constantly being challenged with towers getting taller and more slender. This means more exposure to environmental effects, pushing the boundaries of structural engineering and leading to increasingly challenging loads to be resisted by their foundations.

Most existing high-rise buildings in Dubai are resting on deep foundations, often using circular bored piles with conventional steel reinforcement. Recently, large rectangular foundations, also known as barrettes, have been demonstrated to be more economic for small plots receiving highly concentrated building loads with limited space between foundations. Typically, piles or barrettes 


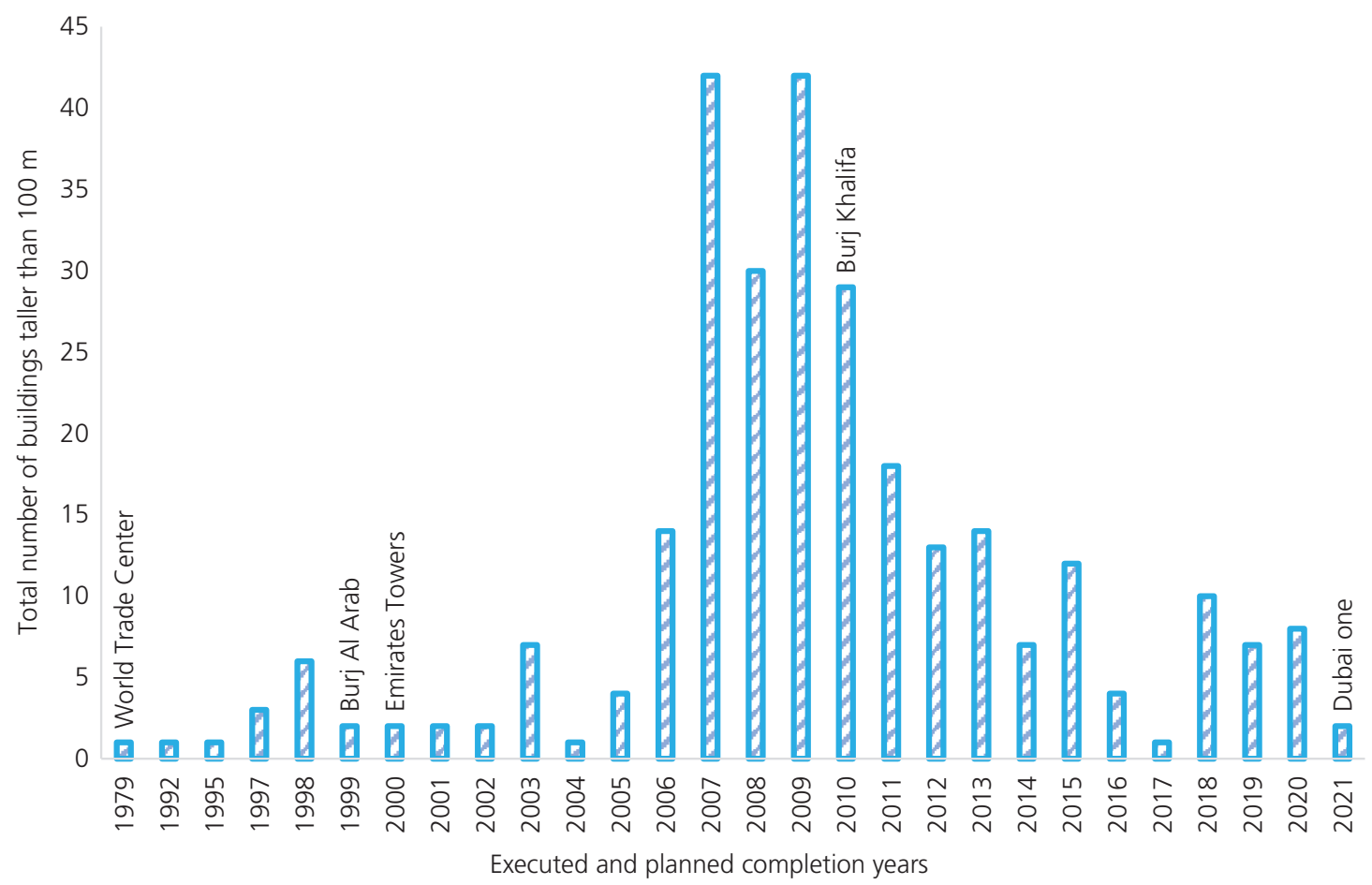

Figure 1. All constructed and planned Dubai high-rise buildings taller than $100 \mathrm{~m}$ (source: the Global Tall Building Database of the Council on Tall Buildings and Urban Habitat (CTBUH, 2018))

are designed using available empirical relationships from published literature, which relate ultimate skin resistance to the results of laboratory testing on rock materials.

Preliminary test piles (PTPs) are often carried out as part of the enabling works mobilisation to verify the design immediately before the construction of working piles, leaving limited optimisation opportunities. This is due to several factors.

- The way that the PTPs have been specified - often full-scale pile load tests are undertaken to the theoretical (conservative) ultimate resistance.

- The test pile lengths are excessive because their geotechnical ultimate resistance is conservatively estimated from empirical relationships.

- The tested piles often reach the capacity of available loading apparatus well before reaching geotechnical failure.

- Back-analysis of PTP results is rarely carried out.

- The cost of the enabling works contracts is typically a remeasurable lump sum value based on rates and an estimated piling volume, before carrying out PTPs. In accordance with Dubai Municipality regulations, the liability for the foundation system lies with the enabling works and site investigation contractors. This means that reductions in piling quantities would raise the risk to both contractors and reduce the contract value of the enabling works contractor.
In the authors' opinion, it is preferable to carry out preliminary pile tests in advance of the enabling works mobilisation; ideally alongside the site investigation works or immediately after their completion. It is acknowledged that this means additional mobilisation costs, but based on current industry practices and the conclusions drawn in this paper, such cost will be vastly outweighed by the savings demonstrable by the test results. In the authors' experience, projects where site investigation and preliminary pile load test data are both available concurrently, at early phases of the design process, give the geotechnical engineer the best chance at developing an economical foundation system for the project, without compromising the level of risk taken by the parties involved. A good example of this successful implementation is Dubai Creek Harbour's The Tower project, where the developer appointed the soil investigation and piling contractor directly at the inception of the project. Preliminary pile tests were performed alongside the site investigation works such that both reports were issued to the client and the designer concurrently, allowing their incorporation directly into the design. This enabled designing an efficient foundation system from its inception.

Contractual arrangements between developer clients and enabling works contractors should be modified such that it is in all parties' best financial interest to optimise pile foundations, reducing quantities and construction time and achieving a lower carbon dioxide footprint on projects.

Although the common industry practice has not enabled establishing the loads required to reach geotechnical failure of pile foundations in 
Dubai, it has generated, over the years, a vast database of projects containing site investigation information as well as reports of PTPs. In many cases, the pile load tests have been carried out using bidirectional load cells; this is mainly such that the high-test loads specified can be safely achieved only with such loading apparatus.

\section{Regional and local geology}

\section{General geology of UAE}

The geology of the Gulf can be related to the closing of the Tethys Ocean (collision of Africa and India with Asia) during the Alpine-Himalayan Orogenesis in the late Cretaceous and early Eocene. It was during this time that the Hajar Mountains were created by the obduction of oceanic sediments forming the Semail Ophiolite Complex.

The landscape of the UAE divides naturally into two distinct regions - the mountain range in the north-east and the remaining area of predominantly desert and coastal sediments. Nowadays, the Gulf shoreline displays the characteristics of a classic carbonate $\left(\mathrm{CaCO}_{3}\right)$ coast: numerous coastal lagoons give way to large areas of sabkha, bounded on their landward side by low escarpments of Tertiary limestone.

A schematic regional cross-section summarising the Quaternary geology of the UAE is presented in Figure 2.

\section{Geomorphology}

The geomorphology of the UAE can be divided into three main regions consisting of the internal sand dune region, the coastal-marine region and the eastern mountain range. Near the coast, the desert sands consist mostly of calcium carbonate material derived from marine sediments. Further inland, the sand consists of quartz grains, the most common rock-forming material and the end product of the chemical weathering of most rock types other than carbonates. Coastal sands derived from marine sediments are mostly white, whereas sands further inland, poor in carbonate, range in colour from yellow to grey or brown to red if coated with a layer of haematite (iron oxide).

\section{Superficial geology of Dubai}

Drowning of the aeolian deposits by transgressing seas and subsequent deflation of coastal dune sands to the level of the capillary zone has formed the inner parts of the coastal sabkha.

The calcareous sandstone typically occurs under the overburden materials with a thickness range of $12-35 \mathrm{~m}$. The sandstones are more gravely towards the main land, while they get thicker towards the coast. The sandstone is typically light-to-medium coloured with varying percentages of carbonate content. The calcareous sandstones tend to have $<50 \%$ of carbonate.

Duricrusts typically occur near the coast and form by hardened accumulation of calcium carbonate, gypsum and halite to give rock-like characteristics. The duricrusts are generally porous and friable with alternating hard and soft layers. They occur at the surface or near the surface. Commonly below the duricrusts, there may be a leached layer, sometimes cavernous, that is deficient in the material which has migrated upwards to form the crust.

Cap rock is a form of duricrust and can overlie loose sands and soft muds in the Gulf region. It was formed in relatively recent times by small changes in the sea level, exposing the sand and allowing a carbonate cementing action to occur by evaporation and moisture.

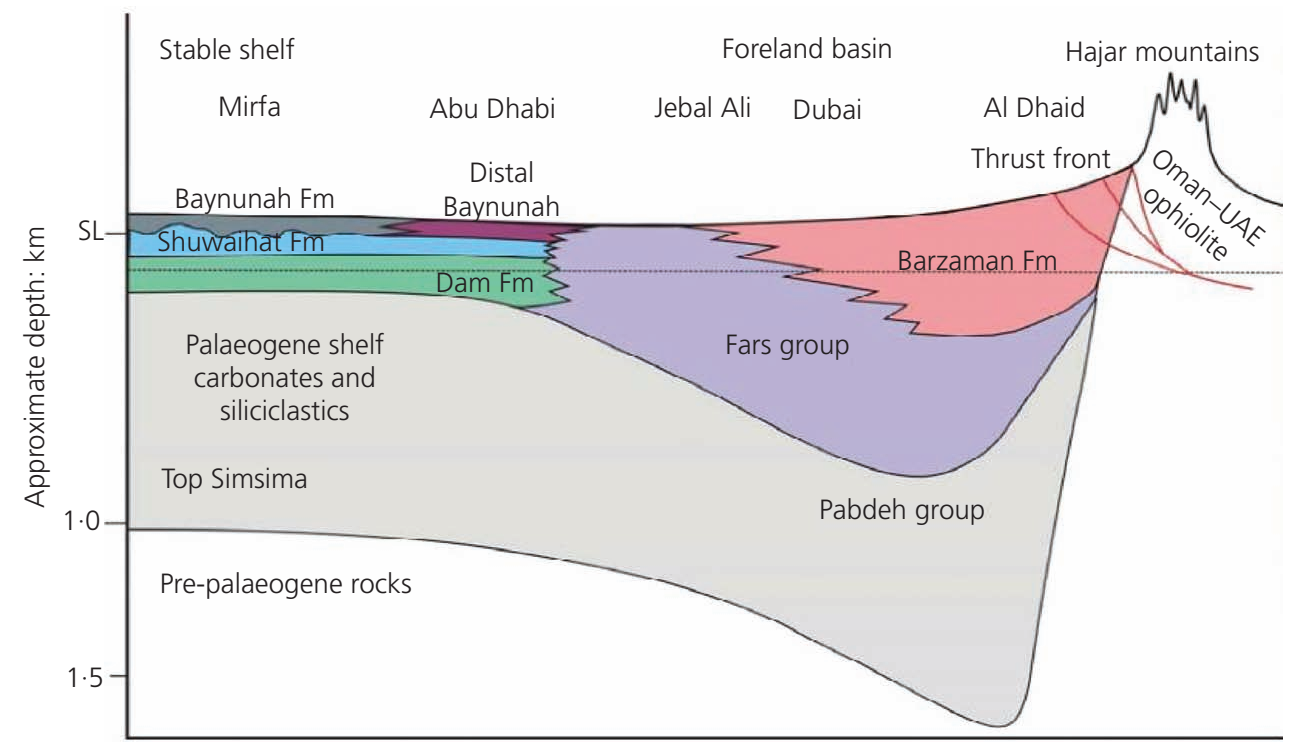

Figure 2. Schematic interrelationships between principal stratigraphic formations, UAE (Macklin et al., 2012). SL, sea level 
Table 1 presents the stratigraphic arrangement of soil and rock units noticed in the Dubai City area according to the book Engineering Geology of Dubai by Sharif and Ahmed (2010).

Furthermore, schematic cross-sections showing the relationship of the geological unit across Dubai District, extracted from Dubai, Sharjah and Sir Bu N'Air Geological Map 1:100000 Series, 100-5 (BGS, 2012), are shown in Figure 3.

\section{Engineering considerations}

The rock units present in the Emirate of Dubai are relatively young on the geological timescale and have not been subjected to much overconsolidation. This means that they are relatively weak and sit at the low end of the rock's competence scale as defined by Carter et al. (2008). Dubai rocks are sometimes referred to as intermediate geomaterials (IGMs), representing a transitional material between soils and rocks outside the lower end of the competency scale.

Table 1. General stratigraphic units of Dubai City

\begin{tabular}{|c|c|c|}
\hline Period & Correlation & $\begin{array}{l}\text { Approximate } \\
\text { thickness: } m\end{array}$ \\
\hline Quaternaries & $\begin{array}{l}\text { Overburden soil deposits (aeolian } \\
\text { sand, beach sand, sabkha) }\end{array}$ & $1-17$ \\
\hline $\begin{array}{l}\text { Early Tertiary } \\
\text { (Pliocene) }\end{array}$ & $\begin{array}{l}\text { Calcareous sandstone and } \\
\text { calcarenite }\end{array}$ & $12-35$ \\
\hline $\begin{array}{l}\text { Mid-Tertiary } \\
\text { (Miocene) }\end{array}$ & $\begin{array}{l}\text { Siltstone/calcisiltite, mudstone } \\
\text { and claystone }\end{array}$ & $>50$ \\
\hline
\end{tabular}

\section{Approval authorities and their requirements}

To the authors' knowledge, there are six different approval authorities that regulate construction for the Emirate of Dubai. Dubai Municipality is the local authority responsible for the largest area of buildable land. Each authority has slightly different requirements, and few are formally captured in writing. This means that face-to-face discussions are essential to understand the project-specific requirements so that they can be implemented to obtain approval. Few authorities employ geotechnical engineering specialists, and the review of geotechnical works such as foundation and shoring designs are routinely entrusted to structural engineers. Most of the Dubai authorities' guidelines refer to Eurocodes or American codes. Recently, a building permit committee which includes all Dubai authorities was established and is currently working towards unifying the Emirate's guidelines.

It would be greatly beneficial to the Dubai construction industry if the local authority's requirements could be reconciled and formally recorded in one or several guideline documents. Abu Dhabi Municipality implemented this several years ago, which added considerable clarity to their construction approval process.

\section{Pile designed as rock sockets}

Pile foundations in Dubai are typically designed as rock sockets. This means that most of the pile's resistance comes from the portion of its length embedded into the in situ rock. Their design may rely on skin friction or end bearing alone or on a combination of both (under certain construction quality controls). This is illustrated in Figure 4. It normally takes larger settlements to mobilise end bearing than skin

W

W Abu Dhabi Formation

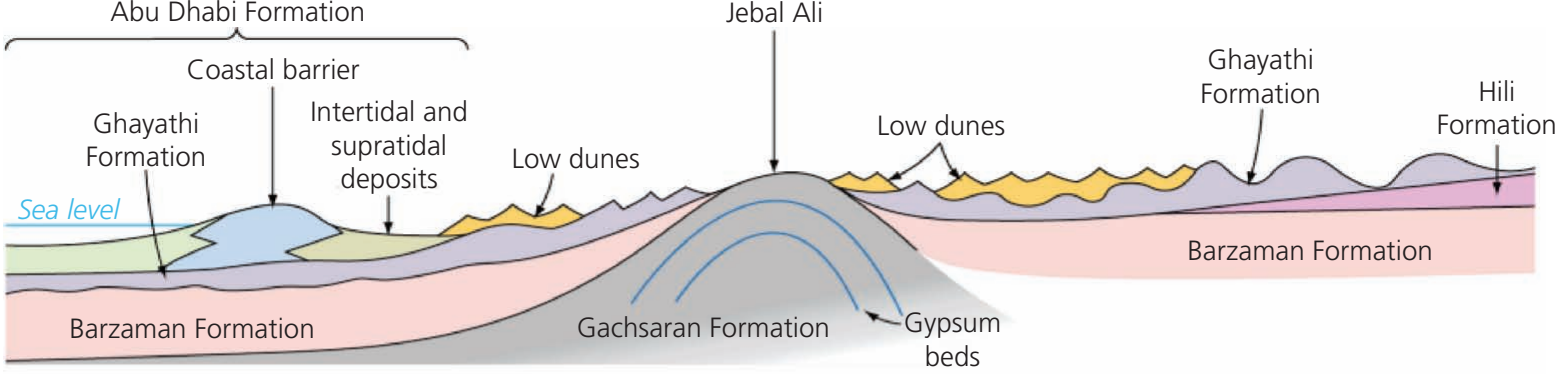

W

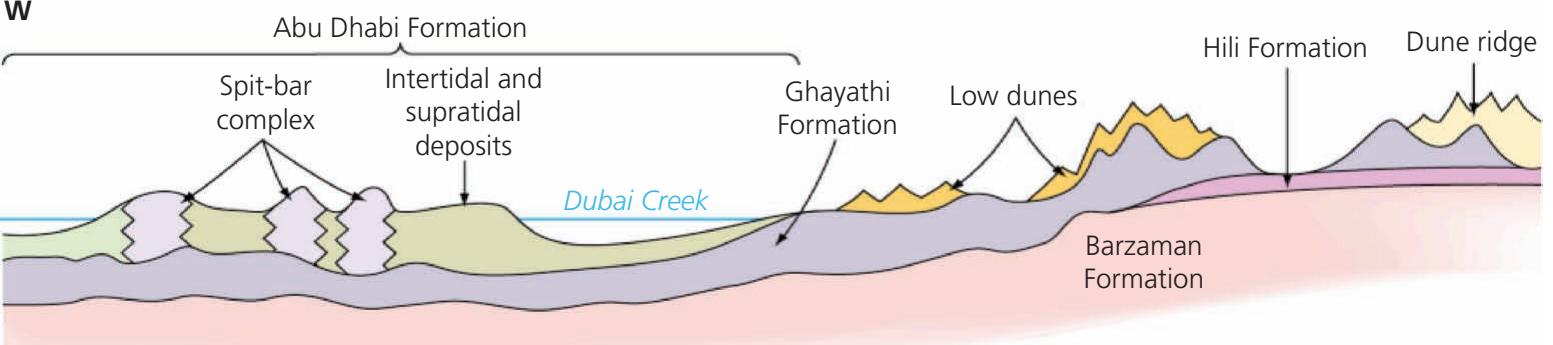

Figure 3. Schematic cross-sections of the geological units across Dubai (BGS, 2012) 
A review of piling industry practices in

Dubai, UAE: proposed UCS-based

correlations

Latapie, Albelda, Abou Samra, Alzaylaie and Sumputh

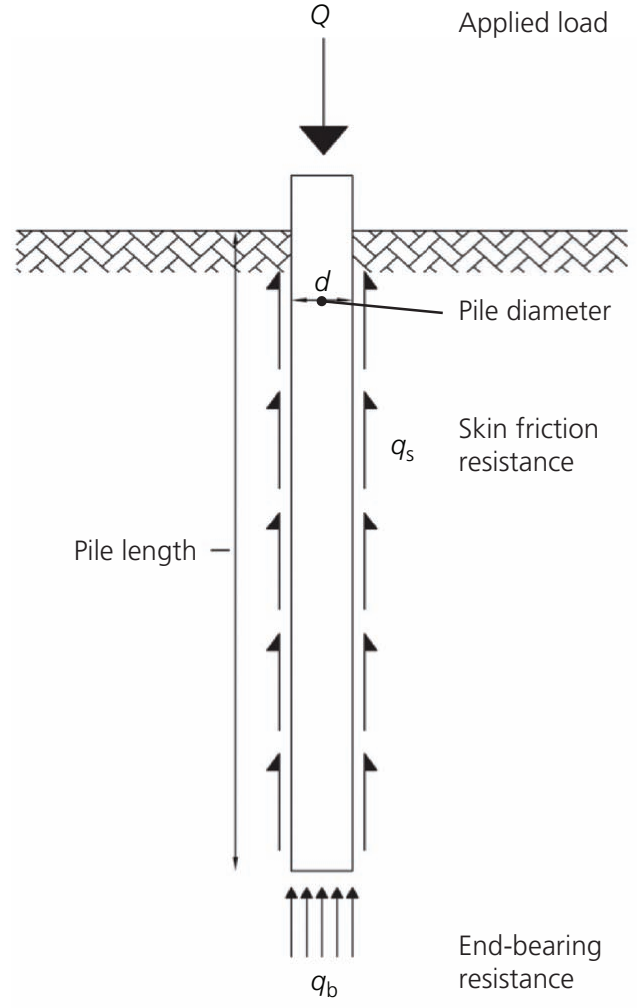

Figure 4. Geotechnical resistance of a single pile (after Bell and Robinson (2012))

friction resistance. When both end-bearing and skin friction resistances are being considered in the design, the estimation of each component should thus be based on a common value of pile settlement. This is to ensure that the foundation design is compatible with the settlement(s) that the supported structure can tolerate. This is illustrated in Figure 5. In the case of piles in weak rocks, the shaft resistance is typically influenced by the side roughness of the pile (an outcome of the construction process) and the strength of the in situ rock material. Design guidance on this type of pile design is provided by the Construction Industry Research and Information Association (Gannon et al., 1999), AASHTO LRFD Bridge Design Specifications (Aashto, 2012), Federal Highway Administration (Brown et al., 2010) and published literature. Other references with useful information on this design technique include Johnston (1991), Kulhawy and Phoon (1993) and Rowe (1987).

Due to the high loads typically carried by foundations supporting high-rise buildings in Dubai, pile foundations tend to be relatively long compared to their diameter and hence are often designed as skin friction piles. This means that, as shown in Figure 5, most of their geotechnical resistance is generated by the shaft skin friction. Consequently, to obtain a cost-effective pile foundation system, estimating correctly the pile's skin friction resistance is essential. This paper focuses predominantly on the derivation of ultimate skin friction values from the results of laboratory testing of rock samples. However, the section headed 'Mobilised end-bearing resistance' includes a discussion that covers the consideration of end-bearing resistance. A vast amount of published literature is available for the design of piles as rock sockets proposing many empirical relationships to derive the pile's ultimate skin friction resistance, usually as a function of a value of UCS for the rock material. The latter is the maximum axial compressive stress that a standard-size cylinder of rock sample can withstand without any confining stress being applied laterally. The section headed 'Dubai: the local context and practices' provides more detail on the relationship available in the published literature.

\section{Published empirical correlations available to the industry}

An extensive literature review allowed the authors to compile a list of available published relationships linking UCS to ultimate

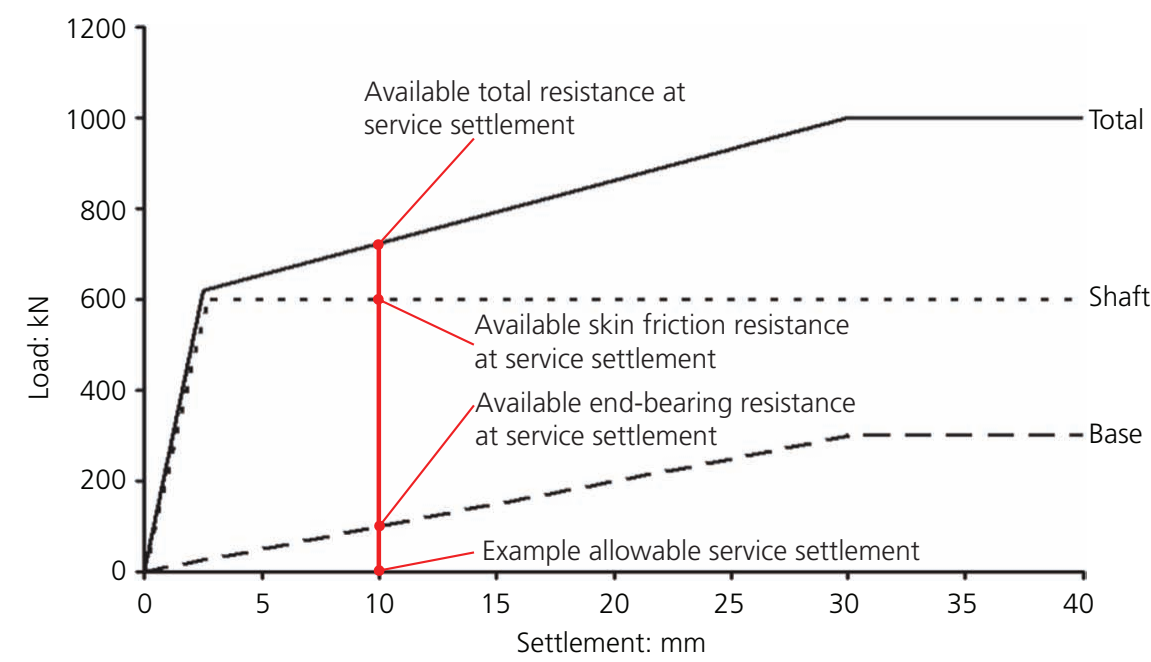

Figure 5. Idealised load-displacement curve for a single pile (after Bell and Robinson (2012)) 
Geotechnical Research

Volume 6 Issue GR2
A review of piling industry practices in

Dubai, UAE: proposed UCS-based

correlations

Latapie, Albelda, Abou Samra, Alzaylaie and Sumputh

Table 2. Summary of published correlations

\begin{tabular}{|c|c|c|c|}
\hline Correlation (year) & Formula & Rock type & $\begin{array}{l}\text { Based on pile } \\
\text { load tests? }\end{array}$ \\
\hline Rosenberg and Journeaux (1976) & $0.375 \times(U C S)^{0.515}$ & Weathered and soft rocks & Yes \\
\hline Horvath (1978) & $0.33 \times(U C S)^{0.5}$ & - & Yes \\
\hline Horvath and Kenney (1979) & $(0.20$ to 0.25$) \times(U C S)^{0.5}$ & Shale and mudstone & - \\
\hline Meigh and Wolski (1979) & $0.22 \times(\mathrm{UCS})^{0.6}$ & en & - \\
\hline Williams et al. (1980) & $\alpha \beta \times($ UCS $)$ & Melbourne Mudstone & No \\
\hline Williams and Pells (1981) & $\alpha \beta \times(\mathrm{UCS})$ & Sandstone, shale and mudstone & No \\
\hline Horvath et al. (1983) & $(0.20$ to 0.30$) \times(\text { UCS })^{0.5}$ & Shale and mudstone & Yes \\
\hline Abbs and Needham (1985) & $\begin{array}{c}0.375 \times(U C S) \text { for UCS < } 1 \mathrm{MPa} \\
0.375+0.1875 \times(\mathrm{UCS}-1) \text { for } \\
\text { UCS }=1-3 \mathrm{MPa} \\
0.75 \text { for UCS }>3 \mathrm{MPa}\end{array}$ & Weak carbonate rocks & Yes \\
\hline Rowe and Armitage (1987) (regular) & $0.45 \times(\text { UCS })^{0.5}$ & - & Yes \\
\hline Rowe and Armitage (1987) (rough) & $0.60 \times(U C S)^{0.5}$ & - & Yes \\
\hline Carter and Kulhawy (1987) & $0.15 \times($ UCS $)$ & - & - \\
\hline Reese and O'Neil (1988) & $\begin{array}{c}0.15 \times(U C S) \text { for } U C S<1.9 \mathrm{MPa} \\
0.2 \times(U C S)^{0.5} \text { for higher UCS }\end{array}$ & - & - \\
\hline Zhang and Einstein (1998) (smooth) & $0.40 \times(U C S)^{0.5}$ & Based on an array of ground conditions - test & Yes \\
\hline Zhang and Einstein (1998) (rough) & $0.80 \times(U C S)^{0.5}$ & results taken from literature & Yes \\
\hline O'Neill and Reese (1999) (IGM) & $\alpha \phi \times(\mathrm{UCS})$ & - & - \\
\hline Charif et al. (2010) & $0.18 \times(U C S)^{0.5}$ & Weak carbonate rocks in the Middle East & Yes \\
\hline
\end{tabular}

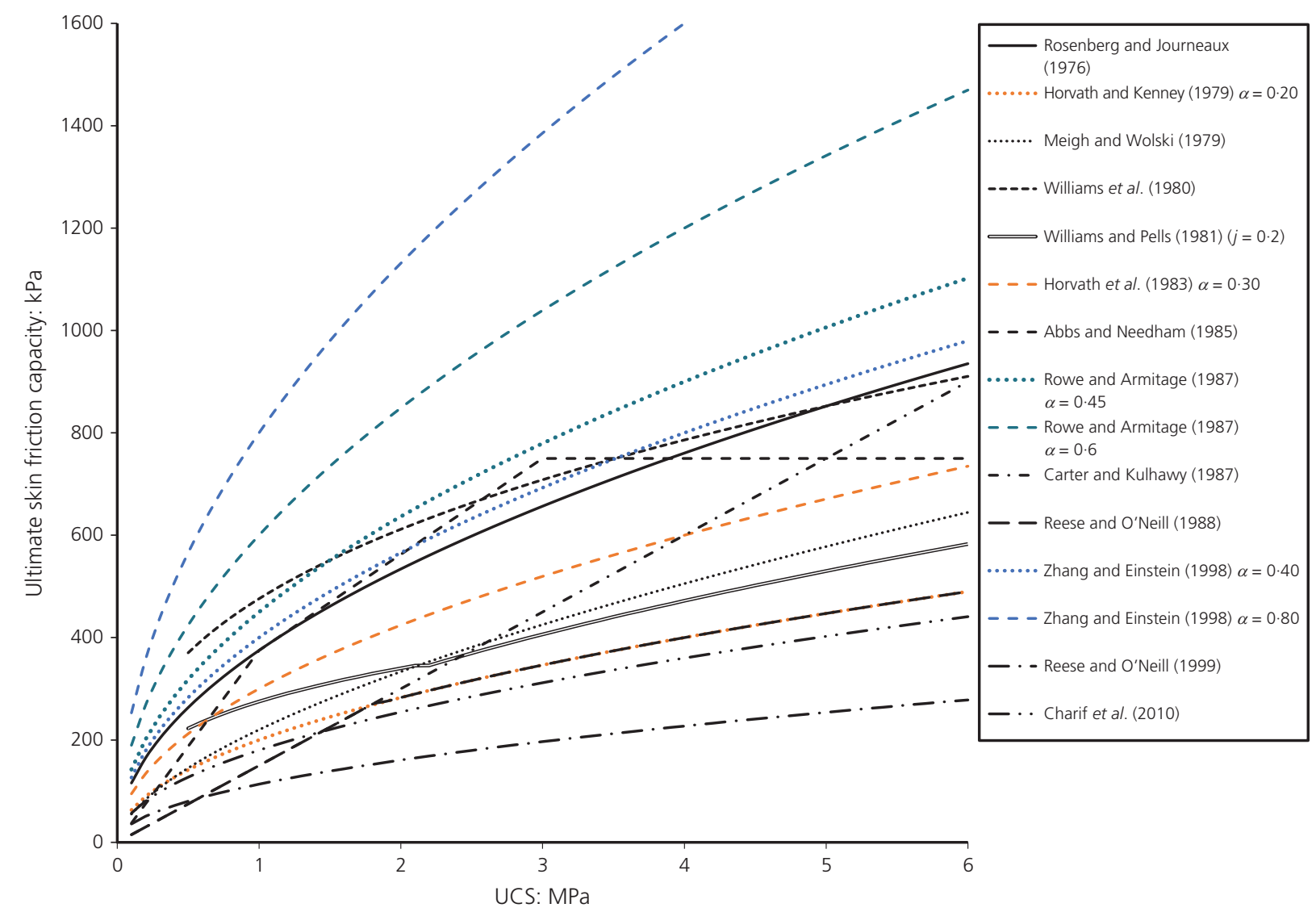

Figure 6. Ultimate skin friction against UCS relationships from the literature 
pile skin friction resistance for weak rocks. These relationships, as summarised in Table 2, span over 34 years and a wide range of rock types and geographical locations. The relationships listed are also illustrated in Figure 6.

Figure 6 shows that the range of ultimate skin friction values obtainable from the different relationships available in the literature is very wide. This is to be expected due to the variations in geological and material properties across the samples considered in the derivation of those relationships. When making the ratio of the upper and lower bound relationships ( 0.80 and $0 \cdot 18$, respectively). a factor of 4.44 is obtained, which is much larger than conventional factors of safety recommended for pile design. Hence, the selection of the relationship used in design has a large influence on the economy of the foundation solution put forward. Despite being the most recent and also based on in situ pile testing of Middle Eastern weak carbonate rocks, the relationship proposed by Charif et al. (2010) predicts lower skin friction values than any other historical relationship. This is rather surprising given that a vast number of foundations have been successfully constructed in Dubai using less conservative relationships. The pile test results used by Charif et al. (2010) do not mention if geotechnical failure was reached. When compared with other published relationships based on in situ testing in carbonate rocks, the skin friction values measured by Charif et al. (2010) are likely low estimates of the in situ rock capacity. All the data available to support the present study suggest that the pile foundations designed for the projects where this information comes from were over-engineered, which is not uncommon in Dubai. In the authors' opinion, the relationship proposed by Charif et al. (2010) is over-conservative for Dubai rock materials and may lead to uneconomical pile foundation designs.

To facilitate the comparison of the data presented in this paper with published literature, the number of representative empirical relationships found in the literature was reduced to what is illustrated in Figure 7. This was done by selecting the relationships most used in Dubai as well as those derived considering the pile side roughness, which the authors believe is an important factor in pile performance. Figure 7 also shows the plots of UCS to design skin frictions used for Burj Khalifa, Pentominium tower and Mall of the Emirates after the publications of Poulos and Bunce (2008), Ibrahim et al. (2009) and Alrifai (2007).

\section{Data published for Dubai}

Several case studies of existing high-rise buildings in Dubai are available in the literature. Table 3 summarises some of the relevant design information related to the pile foundation design for those projects, as presented in the corresponding publications.

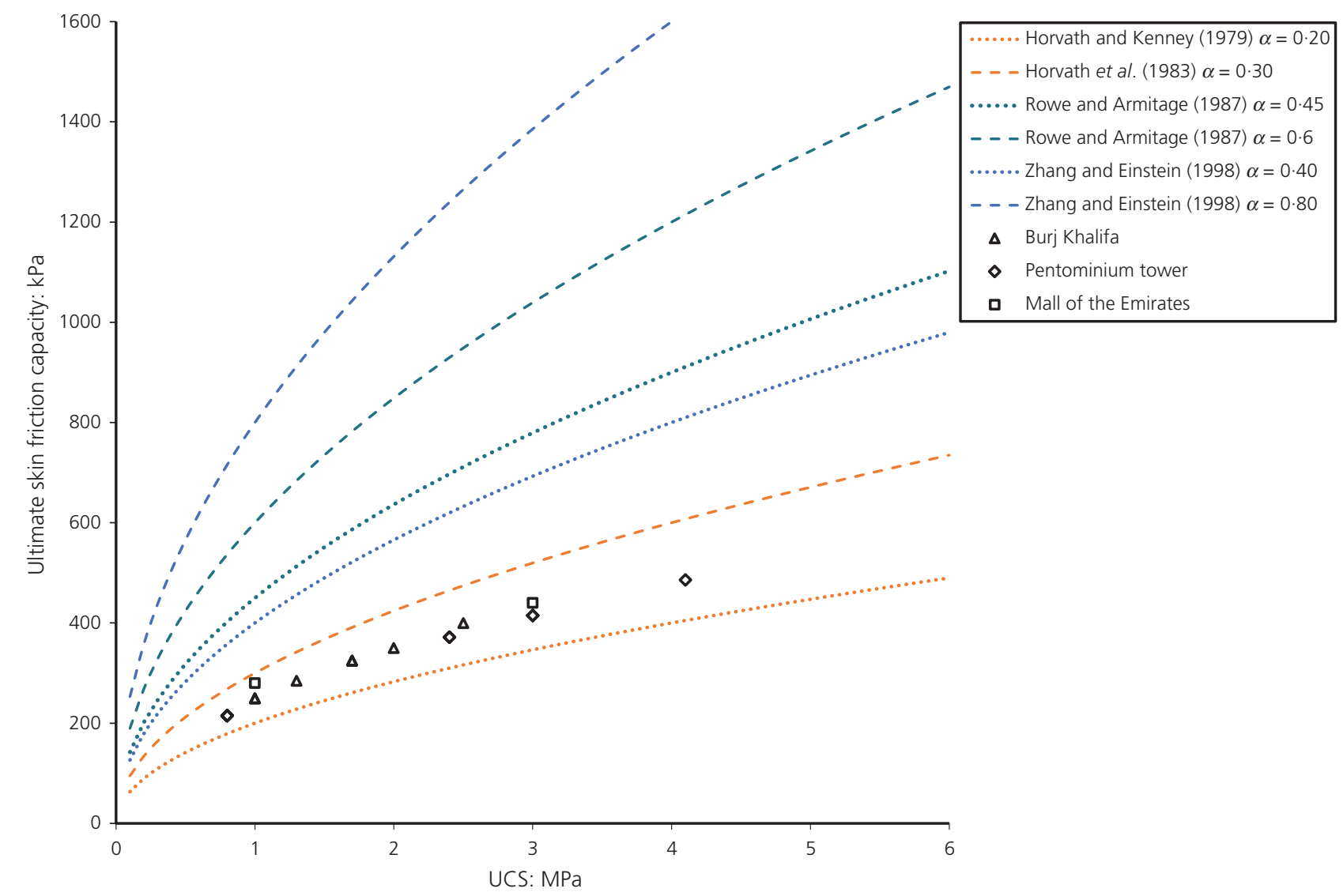

Figure 7. Shortlisted ultimate skin friction against UCS relationships from the literature 
Table 3. Summary of published case studies for high-rise buildings in Dubai

$\begin{array}{lccc}\text { Project name } & \text { Emirates Towers } & \text { Burj Khalifa } & \text { Pentominium tower } \\ \text { Project completion year } & 2000 & 2010 & \text { On hold } \\ \text { Reference } & \text { Poulos and Davids (2005) } & \text { Poulos and Bunce (2008) } & \text { Ibrahim et al. (2009) } \\ \text { Range of design UCS values: MPa } & 0 \cdot 8-1 \cdot 8^{a} & 1 \cdot 0-2 \cdot 5 & 0 \cdot 8-4 \cdot 1 \\ \text { Range of design ultimate skin friction values: KPa } & 200-450 & 250-400 & 215-486 \\ \text { Empirical correlation used } & 0 \cdot 25 \times \text { UCS }^{1 / 2} & 0 \cdot 25 \times \text { UCS }^{1 / 2} & 0 \cdot 25 \times \text { UCS }^{1 / 2} \\ \text { Number of PTPs carried out } & 3 & 6 & 6 \\ \text { Were PTPs brought to geotechnical failure? } & \text { No } & \text { No } & \text { No } \\ \text { Was the pile design be optimised based on the PTP results? } & \text { No } & \text { No } & \text { No } \\ \text { Is the pile design conservative? } & \text { Yes } & \text { Yes } & \text { Yes }\end{array}$

${ }^{a}$ Estimated from the information available in the publication by Poulos and Davids (2005)

In all cases, several PTPs were carried out to support the design activities. Out of 15 tests in total, none was sufficiently loaded to reach geotechnical failure. This means that, although the tests enabled verification of the robustness of the design, they did not enable the optimisation of the pile foundation system. This is likely because the PTPs were dimensioned using the same conservative empirical relationship as used for the permanent piles, precluding the opportunity to establish a more realistic relationship. In the case of Emirates Towers, this is understandable because it was one of the first high-rise projects constructed in Dubai, when little published knowledge was available on the performance of pile foundations. Burj Khalifa (previously known as Burj Dubai) was constructed once more experience had been accrued by the piling industry, but it was to be the world's tallest building during its conception, and, hence, approaching its foundation system with precaution and robustness to limit the overall risk to the project may be understood. Notwithstanding, the information presented in Table 3 relates to prestigious icons of the Dubai skyline and illustrates well the level of conservatism currently embedded in the local piling industry.

\section{The need for a citywide approach}

The enabling works package of high-rise building projects in Dubai represents an important investment which can reach tens of million dirhams. A large portion of this cost is generally allocated to the construction of the deep pile foundations supporting the structure. The material quantities calculated to construct those foundations is directly proportional to their cost and the time required to construct them. Hence, making sure that the number and length of these piles is not higher than what is required to achieve a safe design will have a positive impact in minimising construction costs, programme and carbon dioxide footprint on projects. Given the tight programmes developers routinely work with, shortening the construction duration is often even more important than savings on material quantities to the project's financial planning. This is because it enables releasing the tower units to the market quicker.

The tremendous amount of data and experience available to the Dubai piling industry as well as the positive economic impact of efficient pile foundation design warrants defining a relationship between UCS and ultimate skin friction resistance dedicated to the Emirate of Dubai. Sharing pile design good practices across the industry using a common design relationship recognised by the industry would also facilitate stakeholders' approval (including local authorities).

\section{Pile testing with bidirectional load cells}

The information summarised in this section correspond to a compilation of the authors' recommendation on how to design bidirectional load tests on projects, based on their experience and local standard practices.

\section{A few words about conventional top-down pile load tests}

Traditionally, pile testing was carried out using kentledge or a reaction system made of adjacent piles or ground anchors loaded in tension. The ongoing building height race has led to ever increasing pile foundation loads. Methods using kentledge or a reaction system are usually limited to loads that would not safely accommodate the requirements of most pile load tests undertaken

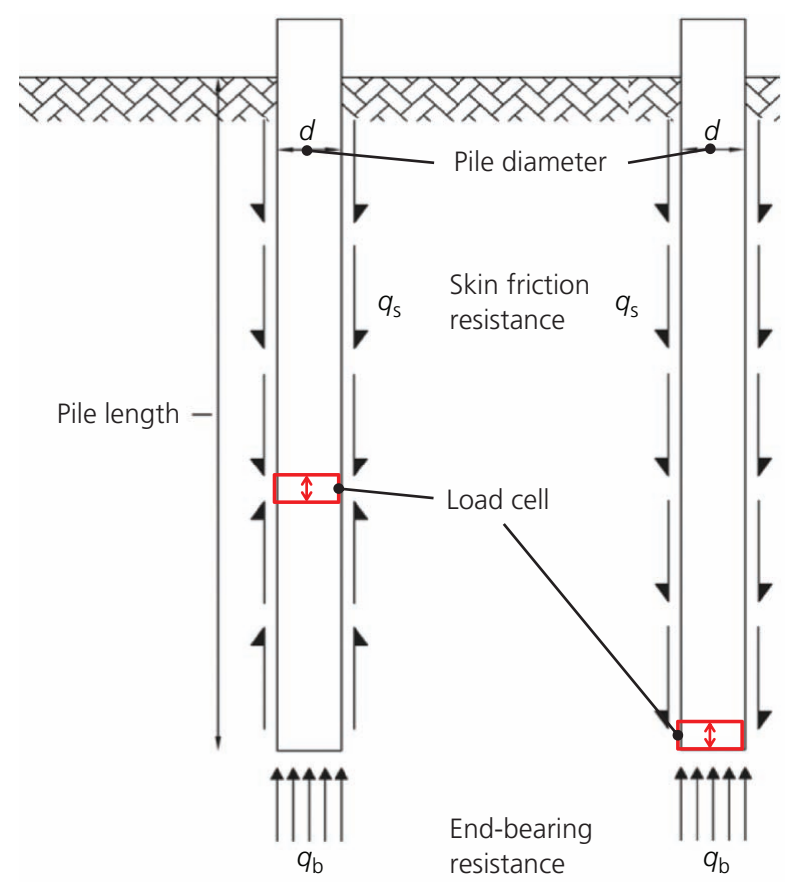

Figure 8. Load application of a bidirectional cell system 
for high-rise buildings constructed in Dubai in recent years. In addition, using multiple reaction points around the test piles leads to difficulty in applying the test load without inducing an unwanted eccentricity to the pile's vertical centreline. Each of these traditional methods takes a large amount of space on-site, which may not always be available and is impractical or simply inadequate for use near- or off-shore.

\section{The bidirectional load cell technique}

The bidirectional load cell technique is an alternative to the conventional top-down test method. The former enables overcoming the limitations of the latter and having direct measurements of the pile-toe load-movement response and the ability to apply much higher test loads (typically $>10 \mathrm{MN}$ ). The bidirectional load cell technique uses one or several sacrificial hydraulic jacks placed at or near the toe of the test pile or barrette (Figure 8). For Dubai projects, it is not usual, however, to place the loading apparatus near the pile toe as the pile design often relies predominantly on skin friction resistance with a comparatively smaller contribution from end-bearing resistance.

In the 1980s, Dr Jorj Osterberg, Professor Emeritus of civil engineering at Northwestern University, Illinois, USA, saw the need for developing a testing apparatus employing a hydraulic jack arrangement placed at or near the pile toe (Osterberg, 1989).
He established a US corporation called Loadtest Inc. to develop the bidirectional pile testing technique which was historically named 'Osterberg cell test' or 'O-cell test' after its inventor (Osterberg, 1998). During about 30 years of commercial application, Loadtest Inc. has developed a practice of strain gauge instrumentation in conjunction with the bidirectional O-cell test, which has vastly contributed to understanding pile response to load application. Over the years, other manufacturers produced alternative apparatuses, leading to a more generic name for this system: 'bidirectional load cell test'.

A bidirectional cell comprises a sacrificial hydraulic piston which is welded to the reinforcement of the test pile through steel plates placed either side of the cell arrangement; as illustrated in Figure 9. When submitted to hydraulic pressures, the piston expands and transfers the loads onto the pile. The load then travels to the side (or shaft) and bottom of the pile to generate a resistance from the surrounding ground. The cell load is applied to the test pile in two equal portions, in opposite directions. The upward load is resisted by the skin friction provided by the upper portion of the test pile. The downward load is resisted by either end bearing alone, if the cell is at the toe of the test pile, or a combination of end bearing and skin friction provided by the bottom portion of the test pile, if the cell is located above the pile's toe.

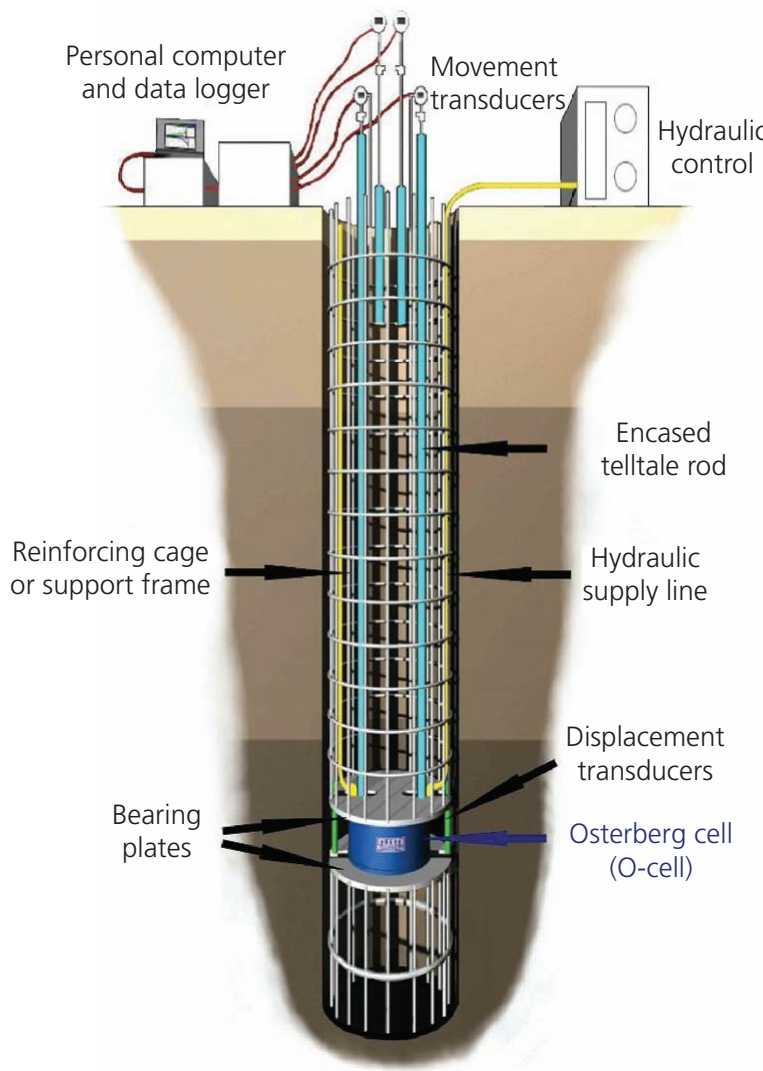

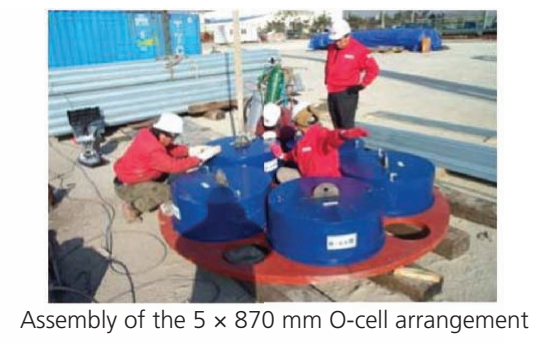
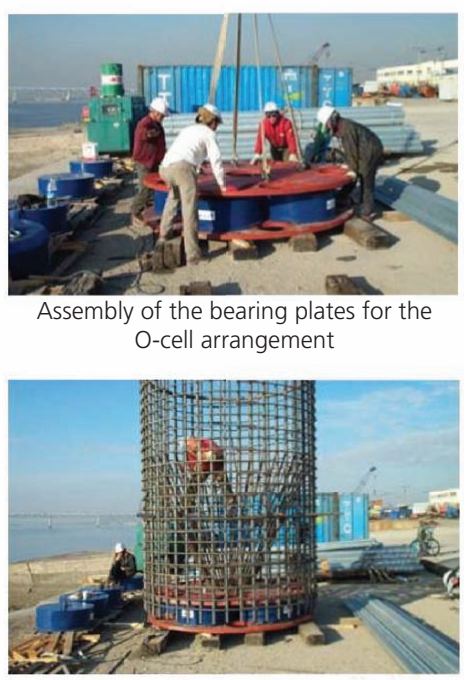

Final assembly of reinforcing cage with O-cells

Figure 9. Illustration of bidirectional cell arrangement, in the case of an O-cell (courtesy of Fugro Loadtest) 
The bidirectional cell is the source of static loading, which means that an external reaction system is not required to test the pile. The top and bottom parts of the pile are effectively tested against each other, which means that selecting the position of the cell within the pile is paramount to the magnitude of the test load applicable to the pile and effectiveness of the test. In cases where high nominal test loads need to be achieved within a single pile, several levels of bidirectional load cells may be used, splitting up the pile into several sections which are each tested independently and sequentially. In other situations, typically for very high load barrette load tests, reinforcement stiffeners are required to even the load distribution from the bidirectional cell arrangement over the length of the barrette pile and prevent localised over-stressing of the weaker part of the barrette's concreting.

Test piles may have one or several levels of cells, depending on the target total nominal test load or the type of information researched in doing the test. In the case of single cell level test piles, as the one shown in Figure 9, two independent static load tests are performed simultaneously and produce two completely separate sets of results (England, 2003).

In addition to its high-quality outputs and low spatial occupation on-site, bidirectional cell testing enables mobilising very high-test loads on a single foundation test. Fugro Loadtest, in partnership with Soletanche Bachy, recently achieved a new world record when mobilising a total test load of $363 \mathrm{MN}$ to a preliminary barrette test for Dubai Creek Harbour's The Tower project. The test barrette was far from being fully mobilised, so the actual barrette capacity would have been significantly higher, again illustrating the advantage of design optimisation from actual static load test results.

\section{Bidirectional load cell test procedure}

\section{General presentation of bidirectional load cell tests}

Figure 9 shows typical set-ups for bidirectional load cells static load test using O-cells. Two examples are illustrated, one of a small pile diameter and length where a single cell is sufficient to achieve the required test loads and another with a large diameter, requiring five cells acting concurrently to achieve the required test load. A bidirectional cell assembly should be designed to provide a nominal capacity of at least half of the required test load in each direction. The bidirectional cell(s) should be calibrated to $30 \%$ above its nominal capacity to enable applying larger test loads in case geotechnical failure of the test pile has not been reached under the nominal test load. Once the cells are calibrated, they should be welded closed prior to shipping from the supplier. The tack welds should remain closed during handling and installation in the pile. To ensure a good test accuracy, each bidirectional cell should have a pressure against force calibration with a maximum linearity error less than or equal to $2 \%$ of the maximum load performed at 25, 75 and $125 \mathrm{~mm}$ cell expansion.

The O-cell is equipped with all necessary hydraulic lines and fittings, and the resulting assembly is mounted on the steel reinforcement cage such that the resultant axial force of the O-cell(s) coincides with the central axis of the foundation. It is recommended that the borehole excavation is callipered prior to receiving the pile's concrete and its reinforcement, to have a good representation of the test pile verticality and dimensions with depth. Other pre-test evaluation of the test pile may be considered to evaluate the concrete integrity prior to the O-cell test by means of ultrasonic cross-hole integrity tests or thermal integrity. These tests enable confirming that the test pile is of sufficient quality before carrying out the test and enables incorporating unavoidable construction differences from the design intent into the interpretation of the test results.

\section{Details of the bidirectional cell assembly}

The bidirectional cell assembly, including the required instrumentation and piping to appropriate levels, is structurally connected to the test pile's steel reinforcing cage. The overall assembly is fabricated by welding two circular steel plates either side of the bidirectional cell(s), with a minimum thickness of $50 \mathrm{~mm}$ and of footprint matching the internal diameter of the test pile's steel reinforcing cage. The plates are necessary to transfer the loads from the cell(s) onto the test pile. Rebars of similar diameter as the main reinforcement are used to construct an apparatus for funnelling the concrete slickline or tremie through the O-cell assembly for concrete placement. It is important to ensure that the steel reinforcement is not continuous across the cell assembly such that the steel reinforcement does not resist the bidirectional loads applied to the test pile. This is shown in Figure 9. Centralisers are used to ensure concentric placement of the load test apparatus, instrumentation and reinforcing steel during the installation of the test pile in the bored hole.

Telltale instrumentation should be installed in pairs along the pile length to measure key features of the pile under static loading. Steel pipe casings that are $0.5 \mathrm{inch}$ dia. $(12.7 \mathrm{~mm}$ dia.) should be used as conduit for telltale rods extending from above working level to the top of the bidirectional cell assembly to give a direct measure of the compression of the pile section above the cell(s). Embedded compression telltale may be used when typical surface measuring methods are impractical (due to access restrictions for example). Similarly, telltale rods in steel pipe casings, attached symmetrically opposed on the reinforcement cage, should be extended from above working level to the pile-toe elevation to give a direct measurement of the toe displacement. The steel pipe casings should be secured on the inner side of the steel reinforcement cage to avoid damage during the lowering of the instrumented cage into the test pile's borehole. In cases where a production pile is selected to be tested using a bidirectional load cell arrangement, an additional set of steel pipes should be installed at the cell break elevation. These serve the dual purpose of venting the bidirectional cell annulus during the test and as post-test grout placement tubes.

Vibrating wire strain gauges (sister bar type) are typically installed at specific elevations to assess the load distribution, and, therefore, knowing the stiffness can infer the skin friction distribution mobilised during the loading test. The strain gauges are installed in pairs perpendicular to the axis of the pile. O-cell tests in working piles are primarily used to evaluate the pile displacement at a proof load. 


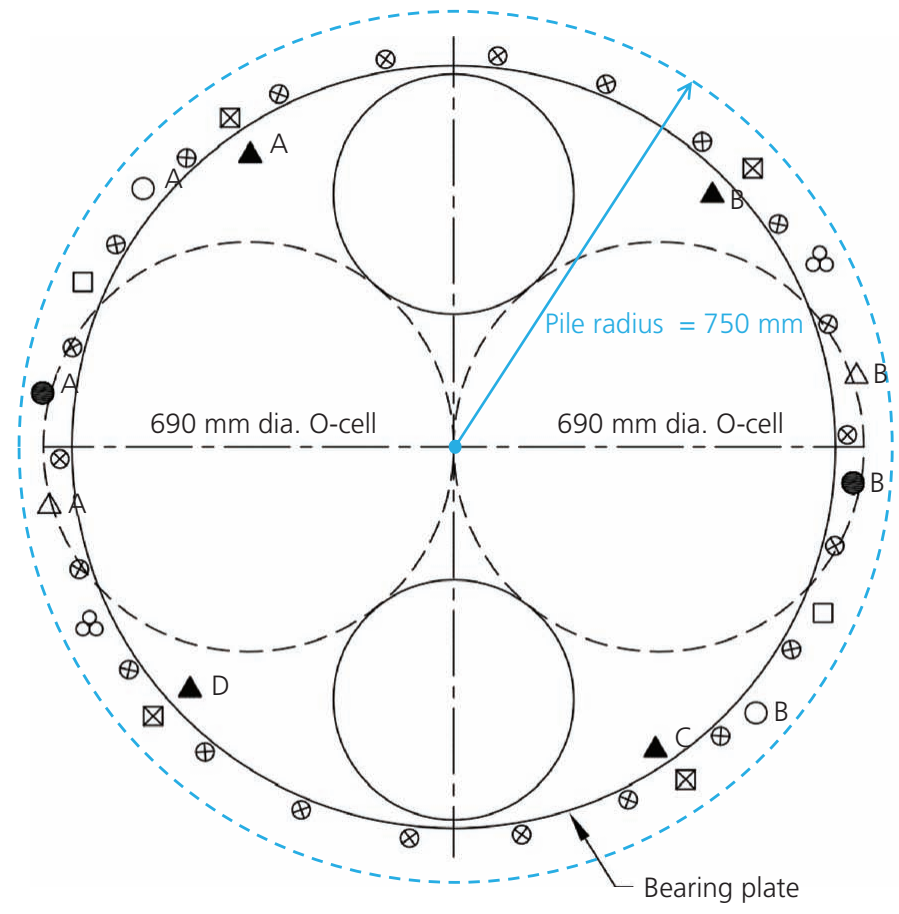

Figure 10. Typical example of an instrumentation layout for a $1.5 \mathrm{~m}$ dia. pile fitted with two bidirectional cells (courtesy of Fugro Loadtest). LVWDT, linear vibration wire displacement transducer

Figure 10 shows a typical assembly layout for a $1.5 \mathrm{~m}$ dia. test pile, incorporating those recommendations.

Finally, the top of the test pile should also be monitored as it provides a stable measurement which can be used to assist the interpretation of the test results. A reference beam may be used for the top-of-pile monitoring, so long as it is firmly supported on the ground at a distance of at least five times the test pile diameter to avoid any ground disturbance due to pile heaving affecting the reference beam. In the Middle East, reference beams are often replaced by multiple automated levelling instruments, enabling the direct measurement of the top of the pile. This way, the direct top-of-pile monitoring can be set to synchronise with the data logging system recording all the other instruments from the test assembly such that all the test monitoring data are recorded with a common timeline on the same test computer.

\section{Test pile loading and measurements}

Before the specified test loading sequence is initiated, a preliminary stage of tack breaking should be carried out. This is the process of pre-loading the bidirectional cell until the manufacturing welds holding them together are broken. To achieve this with minimal impact on the pile test loading sequence, it is recommended that an initial cell expansion of less than $1 \mathrm{~mm}$ is applied, as it is sufficient to disengage the welds completely, allowing the cells to open freely. The tack breaking operation requires high accuracy levels for such a small displacement to be implemented successfully. This may be achieved by embedding linear vibration wire displacement transducers (LVWDTs) into the monitoring system. The transducers can be fixed between the top and bottom plates of the cell assembly and measure directly the expansion between those two plates. This type of transducers is capable of reading displacements with an accuracy greater than $0.01 \mathrm{~mm}$, and their readings are not prone to being affected by temperature fluctuations as the instruments are embedded in the concrete of the test pile and the temperature is generally constant. Creep criterion is checked by analysing the slope of the movements with time to ensure that the criterion is not met just as one point in time but is trending towards and beyond the criteria set. The required settlement rate to be met is typically $0 \cdot 3 \mathrm{~mm} / \mathrm{h}(0 \cdot 1 \mathrm{~mm}$ for $20 \mathrm{~min})$.

The loading sequence can be adapted to suit the pile designer's requirements. To establish the static resistance of test piles, gradual load increments are typically applied to the test pile until reaching the nominal test load. In cases where the ground response to cyclic loading needs to be investigated, test piles can readily be loaded cyclically as required or two or more cell levels can be constructed such that portions of the test pile may be tested in different directions. In such cases, ultimate static resistance as well as skin friction degradation from cyclic loading may be estimated.

Several factors are likely to influence the pile response to axial static loading during a bidirectional static load test. The test pile designer should be aware of such factors and incorporate them into the test specification and result interpretation. A nonexhaustive list of these factors is proposed in the following 
- pile installation equipment and effectiveness/adequacy of construction procedures

- borehole support fluid used

- quality of the cell assembly and its structural connection to the test pile's reinforcement

- elapsed time since initial installation

- pile material properties and dimensions

- soil strata adjacent to and beneath the pile

- test procedure load cycles and interpretation of results

- engineering judgement of the pile test operator and their ability to make quick decisions based on partial readings.

The following direct measurements are recommended to be recorded and displayed live for every minute interval during a bidirectional cell test

- direct top-of-pile movement, monitored using a pair of automated digital survey levels or LVWDTs or linear vibrating wire displacement transducers set over the pile head from a reference beam

- upper pile compression above the cell(s) measured using a pair of telltale rods positioned inside casings, extending from the top of the cell assembly to the top of the pile

- O-cell expansion measured using two pairs of expansion LVWDTs with a minimum travel that exceeds the maximum opening of the cell(s); the pairs of LVWDTs are preferably set up with an equidistant spacing around the cell assembly and parallel to the axis of the pile

- pile-toe displacement measured using a pair of telltale rods positioned inside casings extending from the toe of the pile to the top of the pile.

In addition, the following plate movements can be calculated from the direct measurements to display a live plot of the load-movement curve as the test proceeds.

- The top plate movement is calculated by the sum of the upper pile compression and the top-of-pile movement.

- The bottom plate movement is calculated by subtracting the top plate movement from the cell expansion.

- The lower pile compression below the cell(s) is calculated from the difference between the direct measurements for the bottom plate and pile-toe movement.

The quality and care in interpreting the test results is essential to their incorporation into the project's foundation design. This aspect has been covered in detail in many publications - for example, that of England (2008) - and is not addressed in this paper.

\section{Correction for elastic shortening}

Due to the very nature of bidirectional load testing, the tested pile does not experience elastic shortening the way that it would if it were top loaded. This means that in order to calculate the top load deflection behaviour of bidirectional test results, the recorded displacements during the test must be corrected for additional elastic shortening of the pile if the load was applied to the pile head not mobilised during the test.

\section{Available database and selection procedure}

Since 1979 with the World Trade Centre, over 250 tall buildings (i.e. buildings with $100 \mathrm{~m}$ height or more) have been constructed in Dubai and many more are either in planning phase or under construction. This means that a vast amount of information has been collected by the piling industry over the past 39 years. Through its involvement on some of those projects, proprietary information was gathered by WS Atkins \& Partners Overseas and Fugro Loadtest. Both companies have collaborated to combine their database while respecting the confidentiality wishes of their clients. A total of over 200 pile load test results, from which 91 are preliminary pile load tests, were available to the authors to conduct the study presented in this paper. However, not all results of the available pile load tests were deemed adequate to be included in the scope of works outlined in this study. For instance, pile load tests conducted with conventional reaction systems (such as kentledge or reaction piles) were not considered as their results do not enable easy distinction of skin friction from end-bearing resistances in the overall pile load-settlement behaviour recorded during the tests. Each of the data sets used for this study satisfies the following requirements

- preliminary pile load test conducted using bidirectional load cells with results summarised in a detailed report

- factual site investigation data available nearby the location of the pile load test (actual locations of test piles and boreholes being known).

After applying the selection process just described, a total of 14 data sets from the 91 available were considered suitable to be back-analysed in this study. Project names and details are not provided to maintain their anonymity and respect both companies' confidentiality agreements. Table 4 summarises key information about those data sets, including pile load test and site investigation data.

\section{Definition of geotechnical failure}

It is difficult to define geotechnical failure in such a way that all parties involved in a project understand it and agree with it. Many available publications on pile foundation design have proposed definitions and rules of thumbs. Such definitions merit clear understanding so all engineers can talk the same language and it is often the source of confusion. Bell and Robinson (2012: p. 820) propose the following two definitions based on ultimate and serviceability limit states, respectively.

(i) Ultimate capacity, 'plunging failure' - failure is defined as the load at which settlement continues indefinitely, shown as $P_{\mathrm{u}}$ in [Figure 11]. This is often a theoretical concept rather than a practical reality as most pile tests are not taken to sufficient load to reach this value. Calculation methods based on bearing capacity theory will usually derive a 'plunging failure' load. 
Table 4. Summary of key information from selected data sets

\begin{tabular}{|c|c|c|c|c|c|c|c|}
\hline Item & $\begin{array}{c}\text { Project } \\
\text { database }\end{array}$ & $\begin{array}{c}\text { Pile } \\
\text { diameter: } \\
\text { mm }\end{array}$ & $\begin{array}{c}\text { Pile } \\
\text { length: }{ }^{\mathrm{a}} \mathrm{m}\end{array}$ & $\begin{array}{l}\text { Pile cut-off level: } \\
\text { mDMD }\end{array}$ & $\begin{array}{l}\text { Bidirectional load cell } \\
\text { level: } \mathrm{mDMD}\end{array}$ & $\begin{array}{c}\text { Rock head level: } \\
\text { mDMD }\end{array}$ & $\begin{array}{l}\text { Applied test } \\
\text { load: kN }\end{array}$ \\
\hline 1 & P5-A & 750 & $18 \cdot 3$ & $-3 \cdot 2$ & $-14 \cdot 7$ & $-5 \cdot 0$ & 13500 \\
\hline 2 & P5-B & 1000 & $22 \cdot 5$ & $-3 \cdot 2$ & $-16 \cdot 1$ & $-5 \cdot 0$ & 21750 \\
\hline 3 & P5-C & 1200 & $27 \cdot 6$ & $-3 \cdot 2$ & $-17 \cdot 8$ & $-5 \cdot 0$ & 31500 \\
\hline 4 & P9-A & 1200 & 39.5 & 1.8 & $-25 \cdot 6$ & $-9 \cdot 0$ & 25500 \\
\hline 5 & P15-A & 750 & $16 \cdot 2$ & $-6 \cdot 3$ & $-17 \cdot 1$ & $-12 \cdot 0$ & 8750 \\
\hline 6 & P16-A & 1500 & $48 \cdot 1$ & $-2 \cdot 9$ & $-31 \cdot 9$ & -8.0 & 92500 \\
\hline 7 & P16-B & 1000 & $21 \cdot 1$ & -0.9 & $-30 \cdot 0$ & -10 & 27500 \\
\hline 8 & P17-A & 1500 & 24.9 & $-13 \cdot 4$ & $-29 \cdot 9$ & $-5 \cdot 2$ & 44530 \\
\hline 9 & P17-B & 1200 & $15 \cdot 4$ & $-12 \cdot 7$ & $-22 \cdot 7$ & $-5 \cdot 2$ & 54540 \\
\hline 10 & P19-A & 1200 & $26 \cdot 6$ & -14.5 & $-32 \cdot 1$ & -8.4 & 36000 \\
\hline 11 & P19-B & 1200 & $21 \cdot 3$ & $-14 \cdot 5$ & -29.6 & $-10 \cdot 7$ & 30000 \\
\hline 12 & P20 & 1500 & $27 \cdot 0$ & $-18 \cdot 4$ & $-35 \cdot 8$ & $-15 \cdot 9$ & 55200 \\
\hline 13 & P23-A & 900 & $28 \cdot 3$ & $-15 \cdot 0$ & $-31 \cdot 3$ & -1.9 & 39000 \\
\hline 14 & P23-B & 900 & 28.0 & $-13 \cdot 0$ & $-30 \cdot 3$ & $-1 \cdot 6$ & 31900 \\
\hline
\end{tabular}

${ }^{\text {a }}$ Length of pile is from cut-off level

mDMD, metres Dubai Municipality Datum

(ii) Deformation controlled capacity, ' $10 \%$ failure load' - because the 'plunging failure' load cannot often be practically reached and measured during a pile test. Most codes/standards define failure as the load which is measured at a settlement equal to $10 \%$ of the pile base diameter, shown as $P_{\mathrm{F} 0 \cdot 1}$ in [Figure 11].

The preceding definitions relate to the overall performance of a pile rather than the criteria routinely used during a PTP to determine whether the load increments have been successfully implemented or not. There may be little difference between the two definitions for friction piles. However, defining geotechnical failure as per $(i)$ or (ii) can lead to large differences for end-bearing piles (and piles in which end bearing is a significant component of the total behaviour). Figure 11 illustrates this well with the example of two

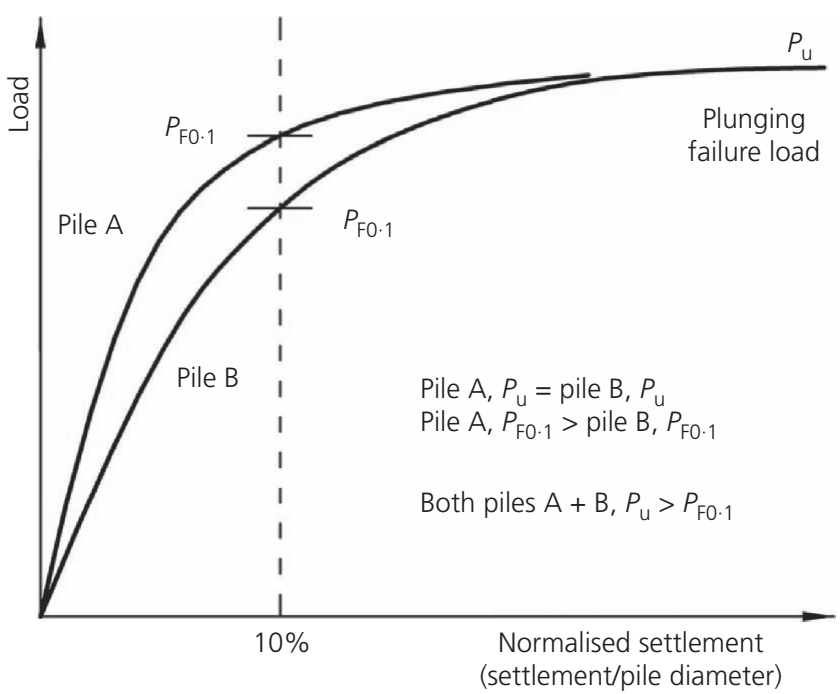

Figure 11. Definition of pile failure (after Bell and Robinson (2012)) piles, $\mathrm{A}$ and $\mathrm{B}$, which have the same ultimate capacity $P_{\mathrm{u}}$ but different values of resistance at a settlement corresponding to $10 \%$ of the pile diameter. The figure also illustrates that if a pile load test stops at a settlement equivalent to $10 \%$ of the pile diameter, the ultimate capacity of the piles is not proven/established.

For PTPs using bidirectional load cells, another way to define geotechnical failure is to continue the test until reaching the full extension stroke of the cells (typically around $200 \mathrm{~mm}$ ) with data analysis to establish the asymptotic behaviour and achieve definition $(i)$.

ASTM D 1143 (ASTM, 2007: p. 2), which specifically deals with static load tests of pile foundation, defines the failure load of such tests as follows

for the purpose of terminating an axial compressive load test, the test load at which rapid continuing, progressive movement occurs, or at which the total axial movement exceeds $15 \%$ of the pile diameter or width, or as specified by the engineer.

For the purpose of categorising the pile load test results used in this paper as well as the interpreting the results of the backanalyses conducted, the authors have decided to define geotechnical failure as the minimum of the two following criteria

- definition (i) after Bell and Robinson (2012)

- total axial movement in excess of $15 \%$ of the pile diameter.

\section{Why do and when to do PTPs}

When comparing the sums of the measured movements which are the direct measurements from the bidirectional cells, ignoring the additional elastic shortening of the piles during loading, most of the test piles settled less than $5 \mathrm{~mm}$. When including the additional elastic shortening (as discussed in the section headed 'Bidirectional 
load cell tests procedure') as presented in each individual load test report, most of the test piles reached settlements not exceeding $15 \mathrm{~mm}$. This means that those piles were not sufficiently mobilised to deduce their geotechnical capacity. This demonstrates that the empirical UCS to skin friction correlations used to design those test piles are conservative for the Dubai ground conditions. It also shows that designing full-scale PTPs using the same empirical relationship and factor of safety as with working piles does not lead to mobilising sufficient movement to determine the geotechnical capacity. This means that those test results are of limited use in enabling the design optimisation of the foundation schemes that they relate to. In other terms, they mobilised a certain amount of skin friction and endbearing resistances without establishing their ultimate values.

In the authors' opinion, sufficient PTPs have been constructed to verify pile construction techniques and the conservative empirical relationships often used in pile design in the Emirate. Hence, PTPs should be carried out with the intention to take advantage of the foundation's additional capacity when available and ideally demonstrate a more realistic rock mass UCS to ultimate skin friction relationship.

Notwithstanding, carrying out PTPs enables the reduction of the project risk related to pile foundations. To that effect, BS 8004:2015 (BSI, 2015) and the third edition of the ICE Specification for Piling and Embedded Retaining Walls (ICE, 2016) recommend that one PTP should be carried out for every 500 working piles on a project. This requirement is not mandatory, and it is to the discretion of the engineer, based on the project's risk level. This is neatly summarised in Table 5, which is an extract from the second edition of the ICE Specification for Piling and Embedded Retaining Walls (ICE, 2007). In the authors' opinion, would the industry share available information more routinely, most new Dubai projects have a low risk level according to the definitions in Table 5.

In order to promote information sharing in the Dubai market and propose a more economical empirical relationship between UCS and skin friction for Dubai rocks, the authors have carried out a comprehensive back-analysis study of selected pile test results. This is explained in detail in the section headed 'Back-analysis'. Figure 12 shows a plot of the load-deflection curves of the PTP results selected for back-analysis. All plots correspond to measured values corrected for additional elastic shortening, in an equivalent top-loading behaviour for the pile. The elastic shortening correction used in each PTP report was consistent. When calculating the equivalent top load elastic shortening for a pile load test that did not reach geotechnical failure, rather than assuming full elastic shortening along the entire pile length, one should match the pile length considered to the portion of the tested pile that mobilised skin friction. This is to avoid overestimating settlements due to elastic shortening in the equivalent top load calculation. Figure 12 shows the load-displacement curves from the PTPs selected for back-analysis.

Most of the plots shown in Figure 12 are linear and do not show evidence of the test pile showing much geotechnical behaviour nor developing geotechnical failure. Only three out of 14 test piles partially developed plasticity, indicating some geotechnical behaviour contribution to the load-deflection behaviour. This is a good illustration that the PTPs were far too large to mobilise ultimate skin friction resistance along the complete pile shaft.

\section{Available site investigation data and parameter derivation procedure}

This section focuses on describing the site investigation information available for rock strata as well as the rock parameter derivation procedure adopted. As part of the project data used, soil strata were also investigated, sampled and tested, but these are not discussed in this paper.

Due to the relatively large database available to support this study, the range of site investigation data available covers a vast area of the constructed Dubai Emirate. In the authors' opinion, this led to obtaining parameters representative of the rock units routinely encountered in the Dubai Emirate. The available data were collected by several different contractors, providing a good representation of the industry's practices.

Rock units typically encountered in Dubai are of young geological age; hence, their strength and stiffness properties are located towards the lower end of the rock competency scale,

Table 5. Typical pile testing strategy based on risk levels

\begin{tabular}{|c|c|c|}
\hline Characteristics of the piling works & Risk level & Pile testing strategy \\
\hline $\begin{array}{l}\text { Complex or unknown ground conditions } \\
\text { No previous pile test data } \\
\text { New piling technique or very limited } \\
\text { relevant experience }\end{array}$ & High & $\begin{array}{l}\text { Both preliminary and working pile tests are essentials } \\
\text { One preliminary pile test per } 250 \text { piles } \\
\text { One working pile test per } 100 \text { piles }\end{array}$ \\
\hline $\begin{array}{l}\text { Consistent ground conditions } \\
\text { No previous pile test data } \\
\text { Limited experience of piling in similar ground }\end{array}$ & Medium & $\begin{array}{l}\text { Pile tests essential; either preliminary and/or working pile tests can be used } \\
\text { One preliminary pile test per } 500 \text { piles } \\
\text { One working pile test per } 100 \text { piles }\end{array}$ \\
\hline $\begin{array}{l}\text { Previous pile test data are available } \\
\text { Extensive experience of piling in similar ground }\end{array}$ & Low & $\begin{array}{l}\text { Pile tests not essential; if using pile tests, either preliminary and/or working tests } \\
\text { can be used } \\
\text { One preliminary pile test per } 500 \text { piles } \\
\text { One working pile test per } 100 \text { piles }\end{array}$ \\
\hline
\end{tabular}




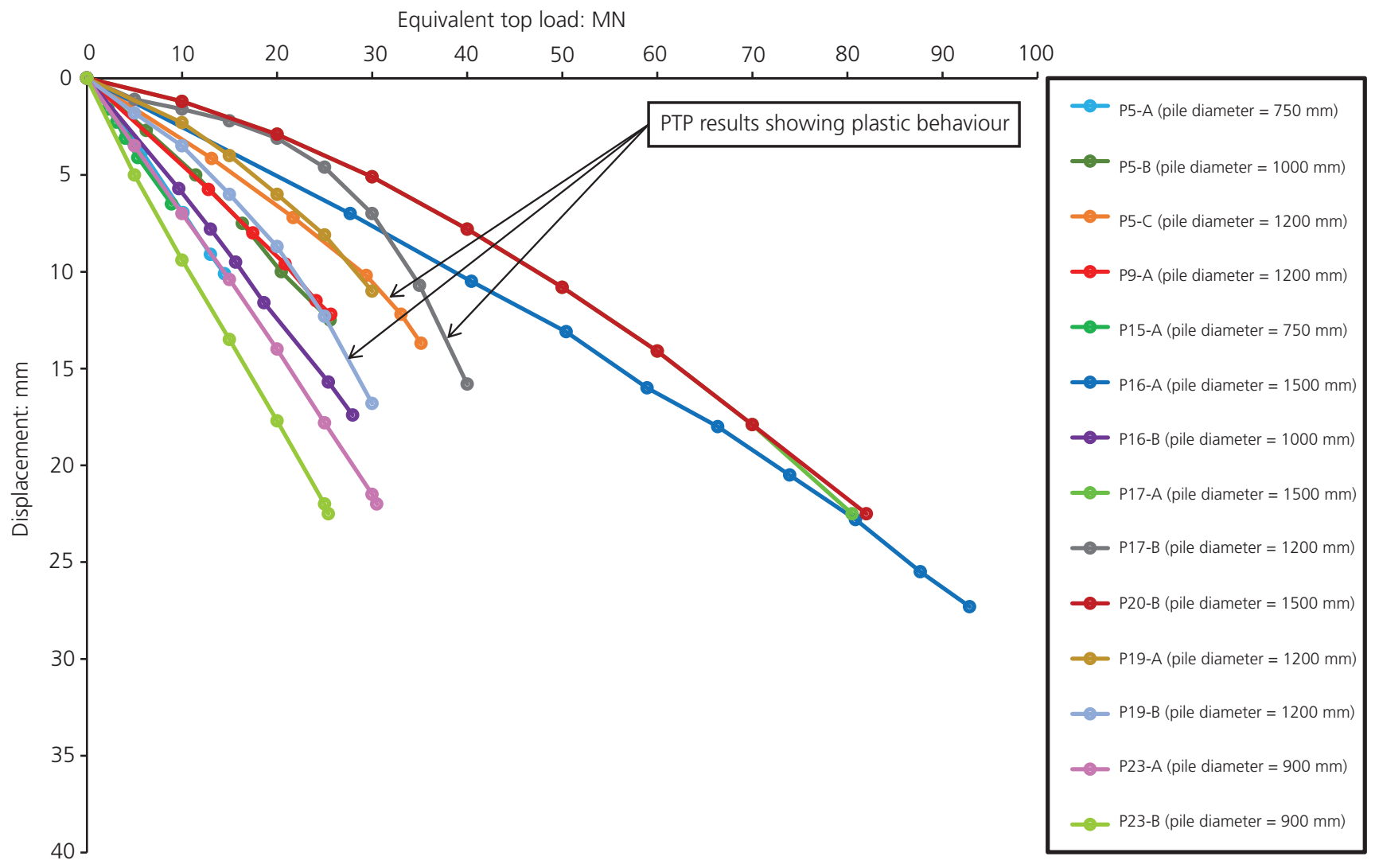

Figure 12. Load-displacement curves from PTPs selected for back-analysis

typically with UCS values lower than $15 \mathrm{MPa}$. This means that these rocks are difficult to retrieve with high recovery as samples are easily damaged during drilling. The accurate characterisation of such rock units is highly sensitive to the quality of the site investigation drilling. Consequently, the scatter of rock quality designation (RQD) and in turn of UCS values is relatively large. Such scatter is representative not only of the variability in rock strength and stiffness but also of drilling induced disturbances.

The parameter that the authors have focused on, in the first instance, to establish a Dubai-specific correlation, is the value of UCS for the rock units. Site-wide average values were plotted with depth for each project and related to the corresponding skin friction values reached during the preliminary pile tests. Figures 13 and 14 illustrate all the UCS values from the authors' database, including their normal distribution along the lower end of the rock competency scale. The authors have used the strength classification from BS 5930:1999+A2:2010 (BSI, 1999) to illustrate the concentration and spread of the data available.

Figure 13 illustrates all the UCS test results gathered for all 14 data sets available for the study. The scatter shows values from less than 1 to $10 \mathrm{MPa}$ for all geotechnical rock units; this is a good illustration of the drilling induced disturbance often encountered during Dubai site investigation works. Figure 14 shows the normal distribution of the same values, which provided a better insight of the most likely rock strengths of the different

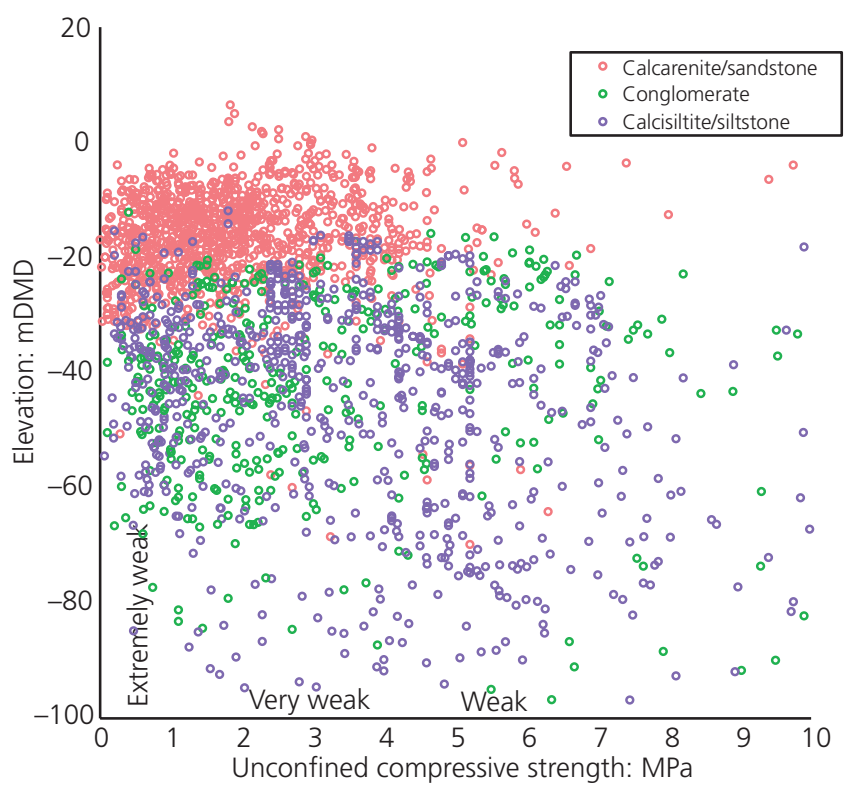

Figure 13. Database's UCS plotted against elevation 


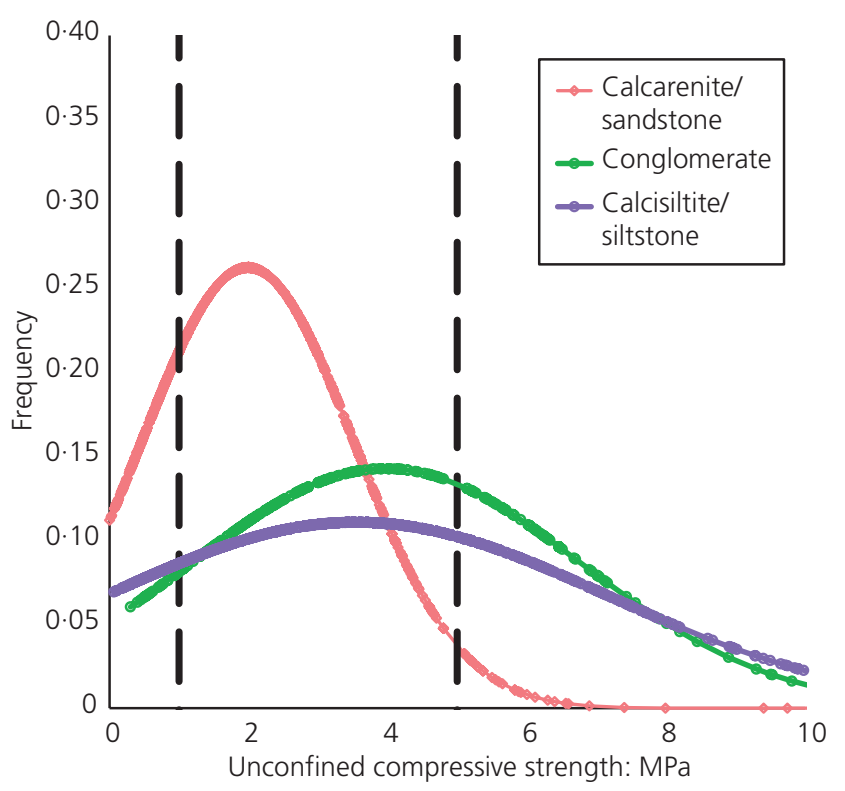

Figure 14. Database's UCS normal distribution curves

engineering units identified. The mean value of UCS for each stratum indicates that the strength of rocks in Dubai can be categorised as extremely weak to very weak rock. The calcarenite/ sandstone unit finds a mean value around $2 \mathrm{MPa}$, whereas the conglomerate and calcisiltite/siltstone units find their mean at 4 and $3.5 \mathrm{MPa}$, respectively. This means that the rock units generally encountered in Dubai are, on average, within the "very weak' range of the rock competency scale.

As a result, the authors have decided to conduct their correlation derivation and back-analysis procedure amalgamating different rock types and slight changes in UCS values to idealised rock units. The following generalised engineering ground model was established

- calcarenite/sandstone

- conglomerate (when encountered)

calcisiltite/siltstone.

This generalisation enabled obtaining a good data spread for the results as well as minimising averaging during interpretation.

For each PTP back-analysed to support this paper, the analysis ground model and its parameters were interpreted from the site investigation borehole nearest to the test pile. In some cases, where a single borehole did not have enough UCS tests to provide confidence on the ground parameters, the test results from the borehole second nearest to the PTP were included to the interpretation procedure. The different rock units encountered in the site investigations were grouped into three main categories, providing a reasonable idealisation of a typical Dubai ground model for the typical elevation range where pile foundations for tall buildings are located. Layers of gypsum are also very commonly encountered in Dubai, but from the available site investigation data, such layers were typically located below the PTPs' toes and hence were not considered relevant to the back-analysis of the pile/rock interface unit skin friction.

Once the ground model was established, design values of each rock unit density and UCS were derived. These were typically taken as average values of the data pool once outliers had been discounted. In design, moderately conservative values of strength parameters are normally adopted, but for the purpose of backanalysis, parameters as close as possible to the in situ condition were required in order to model the pile's real behaviour.

\section{Rock mass classification and characterisation}

The rock mass has been classified using the rock mass rating (RMR) method according to Bieniawski (1989) referencing the geological strength index (GSI) rating by Hoek and Brown (1997) and Carter et al. (2008). The rock mass classification was carried out using the records of the borehole(s) nearest to each test pile under consideration. The drill core quality (RQD) was taken directly from the geotechnical factual report. The other input parameters of the RMR are more qualitative and are based on a visual assessment of the samples recovered (from photographs) as well as on the borehole log descriptions provided by the geotechnical investigation contractor. For the purposes of this study, generalised input parameters for Dubai have been used considering engineering judgement, factual information and site experience.

\section{RMR to Bieniawski}

In the RMR method, in its latest revision, Bieniawski (1989) assigns a rating value to six different parameters which are listed in the following. The sum of all values represents the total RMR which corresponds to a class number and description, shown in Table 1. To avoid confusion with other versions of the RMR method, the symbol $\mathrm{RMR}_{89}^{\prime}$ is used.

A series of rock characterisation parameters such as RMR, GSI, $\mathrm{RQD}$, the rock mass factor $j$, the material constant $\mathrm{m}_{\mathrm{i}}$ and the disturbance factor $D$ were obtained from the borehole logs and supervision records in order to support the derivation of shear strength parameters for rock units, which is mainly based on UCS values. The RMR values used to derive the shear strength parameters followed the Bieniawski (1989) classification with the modifications recommended by Hoek et al. (1995) with regard to the groundwater rating and the rating adjustment for discontinuities orientations. Further details of this process are provided in the next section.

\section{Parameter derivation procedure}

The authors refer to the information presented by Karagkounis et al. (2016) on the Doha rock conditions as the rocks encountered in Dubai present many of the same challenges in terms of site investigation and derivation of engineering parameters. This is of course with the exception of the karstic nature of the Doha Simsima Limestone. 
In order for the pile load test results to be back-analysed using finite-element analyses, the rock parameters tested during the site investigation works need to be correlated with a suitable constitutive model. After carrying out a short trial of the different constitutive models available within the computer software chosen for the modelling (as described in section headed 'Back-analysis'), the authors decided to select the Mohr-Coulomb soil model. The shear strength behaviour of the rock units present in Dubai is typically controlled by the rock mass shear strength rather than discontinuities, and as such, the use of the Mohr-Coulomb failure envelope is deemed reasonable. The Dubai rock units are typically confined to the lower end of the rock competency scale (i.e. UCS $<15 \mathrm{MPa}$ ), and the modifications proposed by Carter et al. (2008) to the Hoek-Brown criterion defined by Hoek et al. (2002) for such rocks were implemented to derive the shear strength parameters used in this study.

The shear strength parameters were derived using both the Hoek-Brown failure criterion presented in the study by Hoek et al. (2002) and the modifications proposed by Carter et al. (2008) for rocks at the lower end of the competency scale. For each rock unit, a couple formed by the angle of internal friction $\phi^{\prime}$ and the cohesion $c^{\prime}$ were chosen such that for the range of confining pressures selected, their equivalent global rock mass strength did not exceed the average from that predicted by the Hoek-Brown failure criterion and the modifications proposed by Carter et al. (2008). Global rock mass strengths were calculated using the relationship introduced by Hoek et al. (2002)

1. $\sigma_{\mathrm{cm}}^{\prime}=\frac{2 c^{\prime} \cos \phi^{\prime}}{1-\sin \phi^{\prime}}$

These shear strength parameters were used in the initial stage of the back-analyses and modified, as required, to match the stress strain curve from the PTP results. In most cases, the parameters derived with the method presented enabled replicating in the model the stress-strain curve by only modifying to the rock mass stiffness. In the authors' opinion, the method used in this paper to derive equivalent Mohr-Coulomb parameters from rock mass properties is adequate for the rock masses encountered in the Middle East region and has been used successfully and refined over many major projects in the region.

The maximum confining pressure considered when deriving equivalent Mohr-Coulomb parameters was conservatively taken at the depth corresponding to the midpoint between the test pile's cut-off level and its toe. This decision was made to ensure that the results presented are robust and may be relied on. This means that future improvements on the UCS to ultimate skin friction relationship are possible, once pile load test results having reached geotechnical failure are available for their back-analysis.

During this process, the selection of an adequate maximum confining stress is essential when deriving equivalent Mohr-Coulomb parameters; this is further discussed by Latapie and Lochaden (2015). Different maximum confining stresses were selected for different strata depths to represent the test's in situ condition.

Rock mass stiffness was estimated using available correlations from UCS results, following the recommendations by Karagkounis et al. (2016) and subsequently back-analysed to match the load-deflection curves provided with the preliminary pile load test reports. This is further explained in the section headed 'Back-analysis'. Table 6 summarises the range of parameters obtained when completing all back-analyses presented in this paper.

In the authors' opinion, the parameters presented in Table 6 are representative of the Dubai rocks typically encountered; using the site investigation and parameter derivation techniques available to the local industry at the time of writing this paper.

Considering that most of the PTP results available for this study did not reach full geotechnical failure, the shear strength parameters presented in Table 6 are likely to be lower bound estimates of reality.

\section{Mobilised skin frictions during testing and identification of outliers}

As explained in the section headed 'Pile testing with bidirectional load cells', test piles using bidirectional load cells are normally instrumented with several strain gauges placed along the length of tested pile. For every strain gauge, skin friction to deflection information is computed and thus is available within the test report. This means that each test report yields a set of skin friction values as output, one per strain gauge level. It is obvious from the review of this information that the highest values of unit skin friction calculated from the test measurements are generally close to the position of the load cell assembly, irrespective of the measured rock's strength. Conversely, the values of measured skin friction gradually decrease as the distance to the load cell

Table 6. Summary of input rock parameters

$\begin{array}{lcccc}\text { Parameters } & \text { Units } & \text { Calcarenite } & \text { Conglomerate } & \text { Calcisiltite } \\ \text { Unit weight, } \gamma & \mathrm{kN} / \mathrm{m}^{3} & 19-22 & 20-24 & 17-22 \\ \text { UCS } & \mathrm{MPa} & 0 \cdot 3-5 \cdot 8 & 1 \cdot 0-10 \cdot 8 & 0 \cdot 5-5 \cdot 2 \\ \text { Angle of internal friction, } \phi^{\prime} & \circ & 38-42 & 40-46 & 27-43 \\ \text { Cohesion, } \mathrm{C}^{\prime} & \mathrm{kPa} & 130-304 & 175-330 & 340-445 \\ \text { Rock mass Young's modulus } & \mathrm{MPa} & 531-3500 & 1490-4675 & 1105-5610\end{array}$


A review of piling industry practices in

Dubai, UAE: proposed UCS-based

correlations

Latapie, Albelda, Abou Samra, Alzaylaie and Sumputh

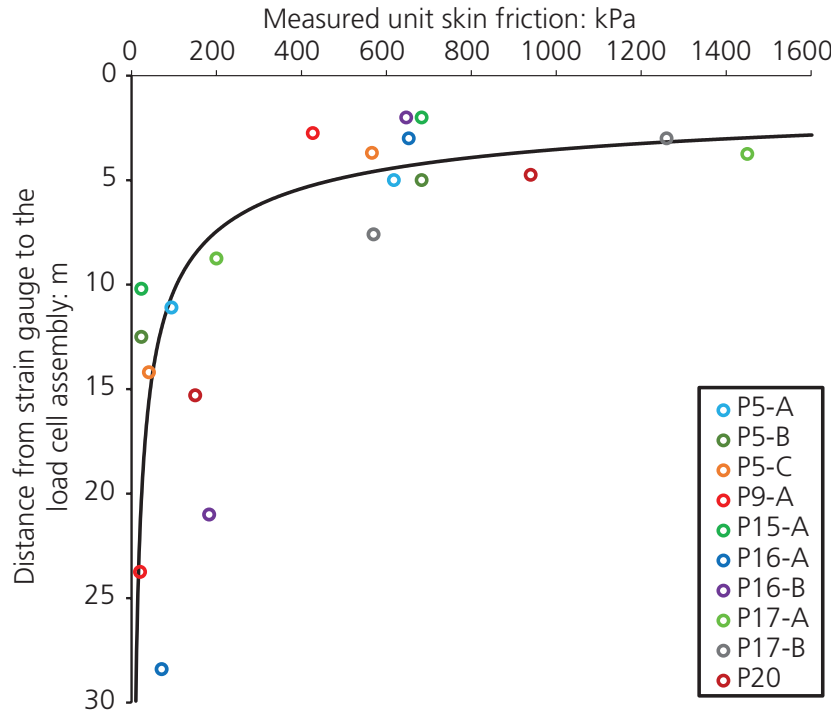

Figure 15. Plot of measured extremum unit skin friction against distance from load cell assembly

assembly increases. This is illustrated in Figure 15, where, for each of the shortlisted PTPs, the maximum and minimum values of mobilised skin friction are plotted as a function of the distance between the measuring strain gauge and the load cell assembly.
This phenomenon is further illustrated in Figure 16 and explained as follows. Pile load tests were historically designed using empirical relationships that underestimate the ultimate skin friction that can be developed/generated by the rock mass. This means that results usually exceed design expectations near the load cell assembly as this is the first volume of rock that will resist the load applied by the cell(s). Consequently, such rock volume resists a higher portion of the test load than planned during the design of test pile; hence, what is left to be resisted by the remaining length of test pile is not sufficient to mobilise the rock's full skin friction resistance. In the authors' opinion, if geotechnical failure is ever reached on PTPs in Dubai, it is only local to the position of the load cell assembly.

Consequently, the values of measured skin friction from the 14 PTPs shortlisted to support the back-analysis exercise are the ones located near the load cell assembly, typically the location where the highest skin frictions were recorded (as shown in Figure 16).

\section{Back-analysis}

The biggest challenge in using the pile load test data available at the time of writing this paper to provide economies to the piling industry is that none mobilised sufficient geotechnical behaviour. This is also true for all PTP results presented in available published literature (as presented in the section headed 'Data published for Dubai'). To overcome this challenge, a comprehensive series of back-analyses

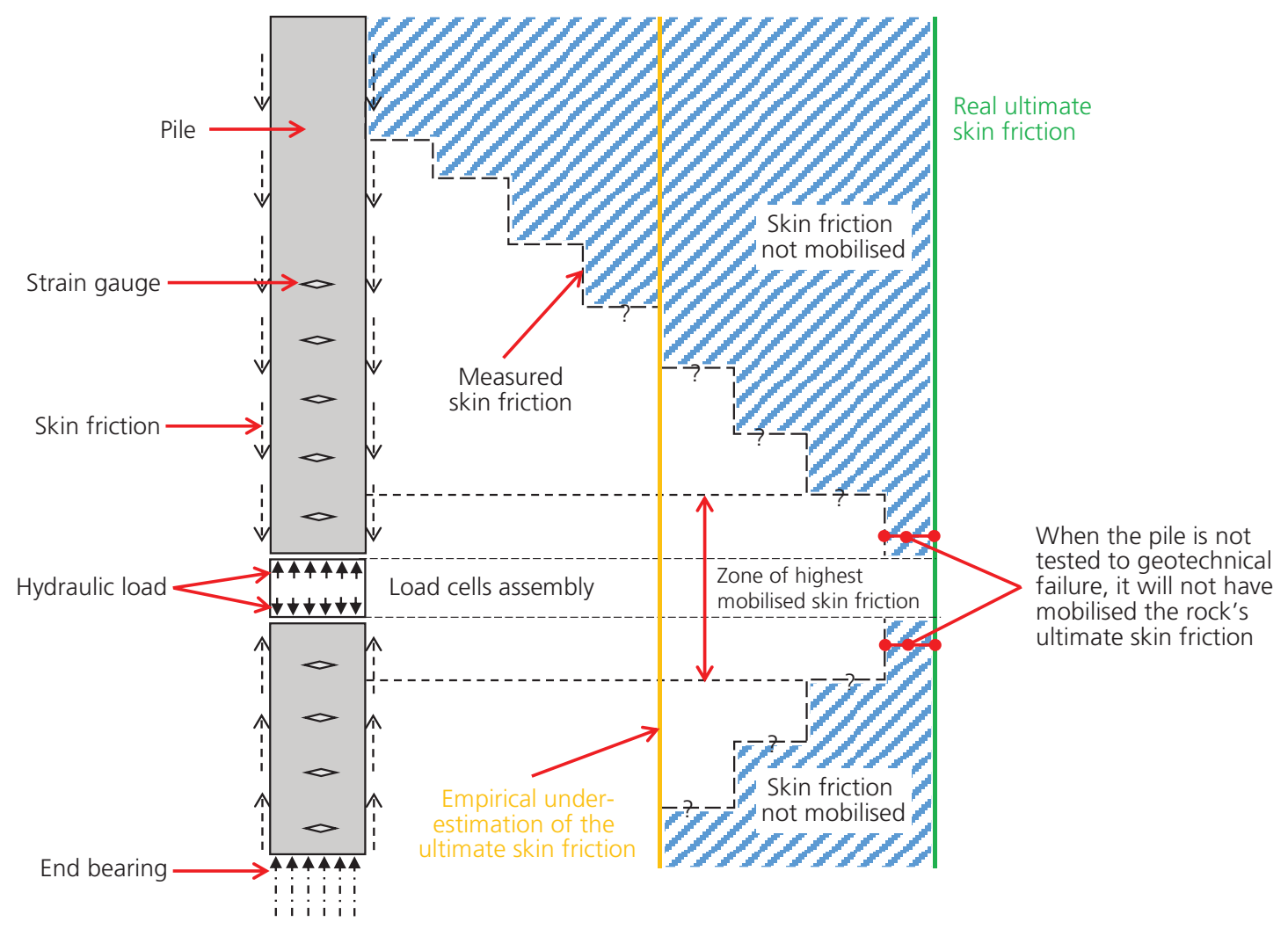

Figure 16. Idealised load distribution diagram for a bidirectional load cell test (for a uniform rock unit) 
was carried out for selected test results. This enabled extrapolating of the likely ultimate pile skin friction resistance should the tests have been loaded to reach geotechnical failure.

However, during this research, the authors were able to identify results suggesting that ultimate skin friction resistance was mobilised locally in some of the PTPs. This means that for several data sets, the ultimate resistance of the rock mass was reached within the rock volumes nearest to the load cell assembly location. This finding enabled validating the shear strength parameter derivation procedure proposed in the section headed 'Available site investigation data and parameter derivation procedure'.

\section{Back-analysis procedure and assumptions}

Out of the 91 pile test results mentioned in the section headed 'Pile testing with bidirectional load cells', ten were selected to be back-analysed. The selection process ensured to obtain a good spread of UCS values to cover as much of the typical range encountered in Dubai rock as possible. In addition, the location of each selected pile load test is known such that the nearest available borehole(s) may be used to establish representative ground models. This way, the stratigraphy and parameters interpreted to derive ground models supporting the back-analyses were as close as possible to the in situ condition of the pile load test.

The finite-element computer program Plaxis 2D was used to carried out the calculations required. The ground materials were modelled using the Mohr-Coulomb constitutive model. and the structural materials used a linear-elastic model and volumetric elements. It is acknowledged that other constitutive models, with a more sophisticated definition of stiffness, as a function of strain, would have enabled more precise modelling of the in situ piles' behaviour, but such gain, in the context of obtaining a reliable ultimate skin friction estimate, was considered small compared to the effort required to back-analyse all necessary parameters.

The models are two-dimensional (2D) and axisymmetrical, using the pile's centreline as axis of symmetry. The pile dimensions and bidirectional load cell were modelled as presented in the pile test result reports. The cell was modelled using a void equivalent to its dimensions, and vertical displacements were applied at its upper and lower horizontal boundaries. The vertical boundary of the cell's void, adjoining the surrounding ground, was constrained laterally to prevent horizontal ground movements during the computed load application procedure. To ensure that the backanalysis models are representative of the corresponding in situ piles, the encountered borehole stratigraphy, from the rock-head to the pile toe, was maintained in the model, with generally, up to three different rock units, as presented in the section headed 'Available site investigation data and parameter derivation procedure'. This means that sand layers above the rock-head level were not modelled, to simplify the interpretation of results. The skin friction contribution from sand layers was ignored, but their presence was modelled by an equivalent overburden surcharge at the rock-head level to ensure that the effective stresses computed

in the models were aligned with the in situ condition. This is deemed an acceptable approximation because the skin friction that may be realised in the sand layers is so little compared to that of the rock units that its influence on the results is small. The selfweight of the pile above the rock-head was also ignored to compensate for the ignored pile-sand skin friction. A typical model set-up and its simplification from the borehole information are illustrated in Figure 17. An interface element was created all around the pile's boundaries to assist the calculation process; however, the interface friction was not reduced such that the output skin friction incorporates any construction effect.

The back-analyses carried out followed a rigorous and systematic procedure for every pile load test result to ensure that the results are directly comparable to each other and may be interpreted together. This is illustrated in the flowchart presented in Figure 18. The procedure includes an iterative process enabling the gradual modification of stiffness and shear strength properties of the rock materials, until the PTP results are matched by the model outputs, following a curve-fitting exercise. First, the stiffness was varied to obtain the correct load-deflection curve inclination. Then, the shear strength was changed to provide a curvature match to the development of the plastic zone. In most cases, the input shear strength parameters obtained from the derivation procedure detailed in the section headed 'Available site investigation data and parameter derivation procedure' enabled matching very well the PTP results when the load-deflection curves change from an elastic to a plastic response. Only a few iterations of the rock stiffness were required to obtain a complete match to the measured data. An output example is shown in Figure 19. The change in skin friction at $-20 \mathrm{mDMD}$ is representative of a strata change, the deeper unit having higher UCS values and hence a large frictional resistance.

Borehole information

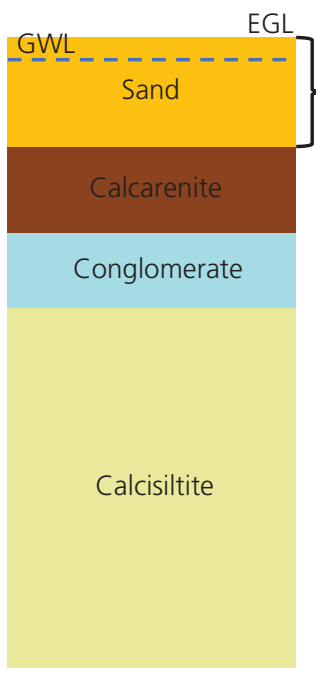

Figure 17. Typical Plaxis model set from borehole information. $E G L$, existing ground level; GWL, ground water level

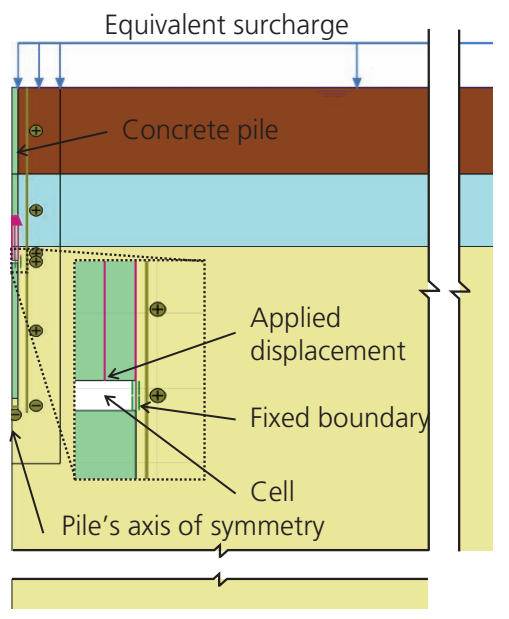




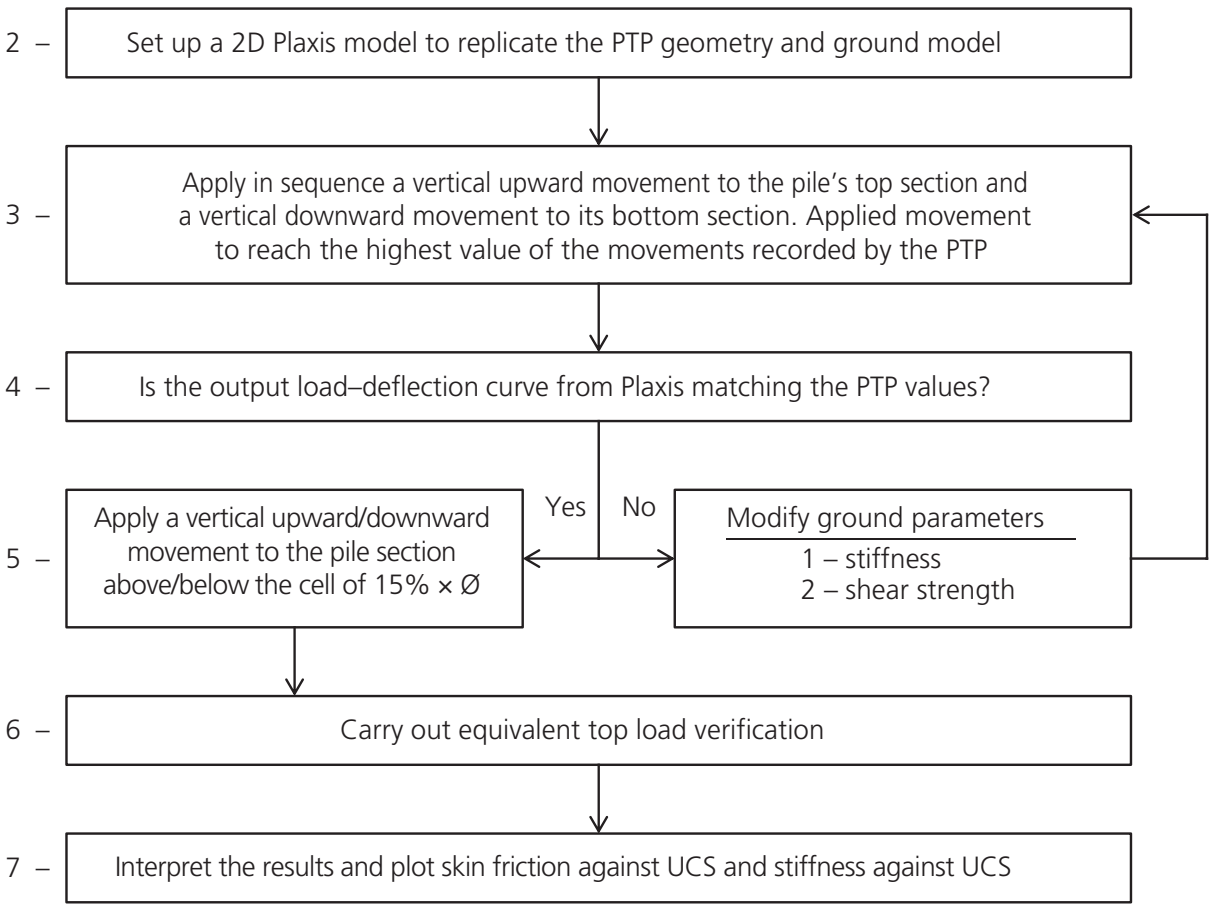

Figure 18. Back-analysis procedure

The interpreted ultimate skin friction from the back-analysis results was taken from realising a top loading of the entire pile up to a displacement of $15 \%$ of the test pile's diameter, which is the adopted definition of geotechnical failure, as explained in the section headed 'Definition of geotechnical failure'.

\section{Results and proposed correlations}

\section{Rock mass stiffness and UCS}

Table 7 summarises the stiffness values recommended in the available site investigation reports as well as the values obtained during the back-analyses. The values provided in the site investigation report come from UCS test results where stiffness is measured. Only a few of the available site investigation reports from the PTPs shortlisted to be back-analysed contained rock mass stiffness values.

The data presented suggest that using UCS tests to measure Dubai rock stiffness generally provides a gross underestimation; with ratios varying from 4 to nearly 15 . These results are in good agreement with the results presented by Haberfield (2013). His paper presents results from pressuremeter testing and cross-hole seismic surveys which measured stiffness values closer to those back-analysed in this paper.
Figure 20 presents a plot of the back-analysed rock mass stiffnesses against their corresponding UCS values. The quantity of data available combined with the scatter found when plotting the rock's stiffness as a function of its UCS value was such that a single correlation could not be interpreted. However, the complete set of back-analysed stiffness values are within the lower and upper relationships defined as follows

\section{2. $E_{\mathrm{LB}}=430 \times \mathrm{UCS}$}

3. $E_{\mathrm{UB}}=1720 \times \mathrm{UCS}$

where LB and UB stand for lower and upper bounds, respectively. The lower and upper bound relationships proposed are limited to the UCS range of 0-6 MPa.

Figure 20 also shows the values presented in the site investigation reports as well as values from published literature. It is interesting to note that the information from site investigation reports and published literature agree well in their prediction of rock mass stiffness in relation to UCS values. In the authors' opinion, this is because the published literature available corresponds to iconic 
A review of piling industry practices in

Dubai, UAE: proposed UCS-based

correlations

Latapie, Albelda, Abou Samra, Alzaylaie and Sumputh

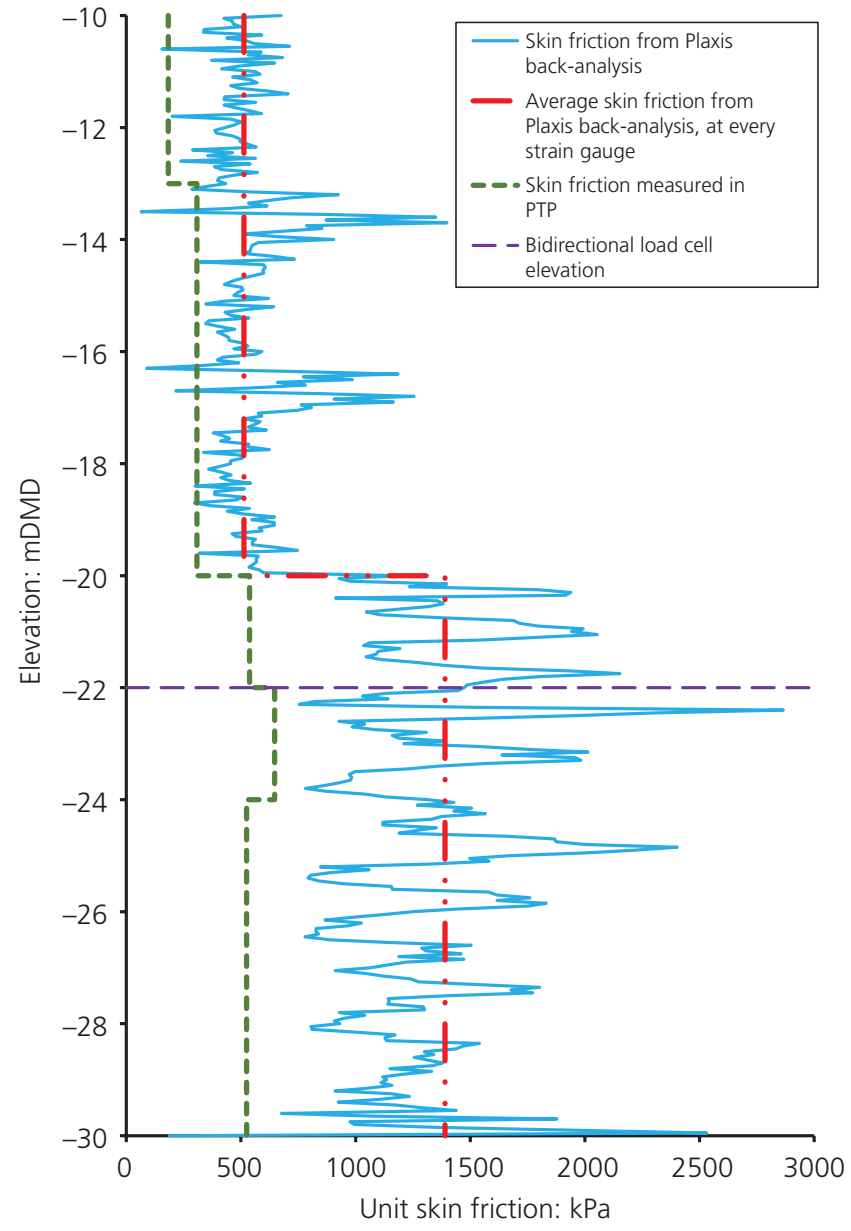

Figure 19. Back-analysis output example
Table 7. Site investigation report recommended and backanalysed rock stiffnesses

\begin{tabular}{|c|c|c|c|c|c|}
\hline $\begin{array}{l}\text { PTP } \\
\text { ref. }\end{array}$ & Rock unit & $\begin{array}{l}\text { UCS: } \\
\text { MPa }\end{array}$ & $\begin{array}{l}E \text { from UCS } \\
\text { testing: } \mathrm{MPa}\end{array}$ & $\begin{array}{l}\text { E from back- } \\
\text { analysis: MPa }\end{array}$ & Ratio \\
\hline P5-A & Calcarenite & $3 \cdot 1$ & 375 & 3500 & $9 \cdot 3$ \\
\hline P5-B & Calcarenite & $2 \cdot 1$ & 375 & 1800 & $4 \cdot 8$ \\
\hline P5-C & Calcarenite & $1 \cdot 6$ & 375 & 1360 & 3.6 \\
\hline P9-A & Calcarenite & $2 \cdot 0$ & 275 & 3400 & $12 \cdot 4$ \\
\hline P15-A & Calcarenite & $2 \cdot 0$ & 375 & 1500 & $4 \cdot 0$ \\
\hline \multirow[t]{2}{*}{ P16-A } & Calcarenite & $1 \cdot 6$ & 200 & 2720 & $13 \cdot 6$ \\
\hline & Calcisiltite & $3 \cdot 0$ & 750 & 5100 & $6 \cdot 8$ \\
\hline P16-B & Calcarenite & $1 \cdot 0$ & 200 & 850 & $4 \cdot 3$ \\
\hline
\end{tabular}

projects which were designed at a time when local site investigation practices were not as developed as at the time of writing this paper, and little published information was available on Dubai ground conditions and cautious estimates were made. The publication by Poulos and Bunce (2008), on the design of the Burj Khalifa's foundation, includes a plot, for wing $\mathrm{C}$ of the building, of the estimated settlement and measured settlement until 18 March 2007, when $75 \%$ of the dead load would have been acting on the foundation. The predicted settlement prorated to the intermediate construction stage is approximately $60 \mathrm{~mm}$, while the corresponding measurement was $30 \mathrm{~mm}$. This means that the measured settlement was half of the predicted settlement. Assuming that the load-settlement relationship for the building was linear, this means that the design stiffness values of the modelled rock were underestimated by $50 \%$. Interpolating linearly the Burj Khalifa values, the following relationship (where BK stands for Burj Khalifa) is obtained

4. $E_{\mathrm{BK}}=200 \times \mathrm{UCS}$

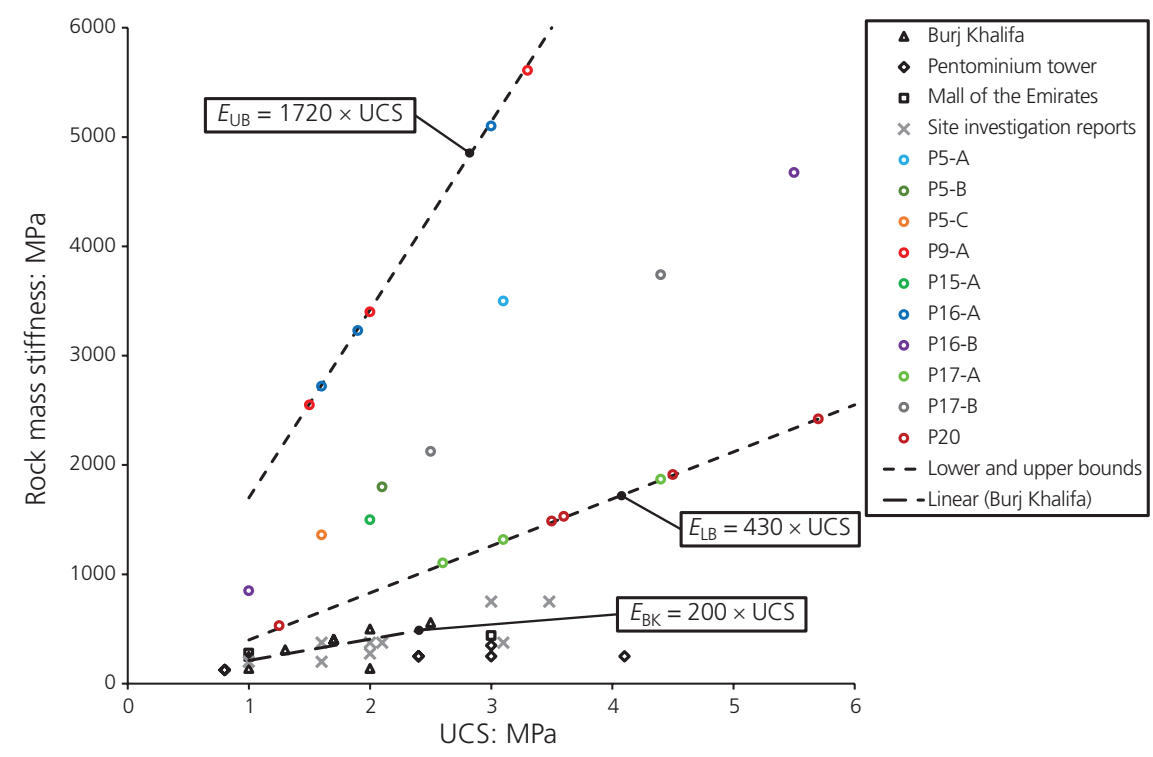

Figure 20. Back-analysed rock mass stiffness plotted against UCS 
Table 8. Measured and back-analysed skin frictions

\begin{tabular}{|c|c|c|c|c|}
\hline \multirow{2}{*}{$\begin{array}{l}\text { PTP } \\
\text { ref. }\end{array}$} & \multirow[b]{2}{*}{ Rock unit } & \multirow{2}{*}{$\begin{array}{l}\text { UCS: } \\
\text { MPa }\end{array}$} & \multicolumn{2}{|c|}{ Skin friction: $\mathrm{kPa}$} \\
\hline & & & $\begin{array}{l}\text { Mobilised } \\
\text { in PTP }\end{array}$ & $\begin{array}{l}\text { Back-analysis- } \\
\text { estimated ultimate }\end{array}$ \\
\hline P5-A & Calcarenite & $3 \cdot 1$ & 618 & 1155 \\
\hline P5-B & Calcarenite & $2 \cdot 1$ & 683 & 785 \\
\hline P5-C & Calcarenite & 1.6 & 566 & 680 \\
\hline \multirow[t]{3}{*}{ P9-A } & Calcarenite & 2 & 143 & 892 \\
\hline & Conglomerate & 1.5 & 195 & 786 \\
\hline & Calcisiltite & $3 \cdot 3$ & 427 & 1007 \\
\hline P15-A & Calcarenite & 2 & 683 & 850 \\
\hline \multirow[t]{3}{*}{ P16-A } & Calcarenite & 1.6 & 289 & 713 \\
\hline & Conglomerate & 1.9 & 501 & 1147 \\
\hline & Calcisiltite & 3 & 653 & 1240 \\
\hline \multirow[t]{2}{*}{ P16-B } & Calcarenite & 1 & 308 & 513 \\
\hline & Conglomerate & $5 \cdot 5$ & 647 & 1390 \\
\hline \multirow[t]{3}{*}{ P17-A } & Calcisiltite_1 & $3 \cdot 1$ & 520 & 714 \\
\hline & Calcisiltite_2 & $2 \cdot 6$ & 1190 & 610 \\
\hline & Calcisiltite_3 & $4 \cdot 4$ & 1450 & 1076 \\
\hline \multirow[t]{2}{*}{ P17-B } & Calcisiltite_1 & $2 \cdot 5$ & 1260 & 1040 \\
\hline & Calcisiltite_2 & 4.4 & 840 & 1211 \\
\hline \multirow[t]{5}{*}{ P20 } & Calcarenite & $1 \cdot 25$ & 210 & 540 \\
\hline & Conglomerate & $3 \cdot 5$ & 940 & 916 \\
\hline & Calcisiltite_1 & $3 \cdot 6$ & 740 & 809 \\
\hline & Calcisiltite_2 & $5 \cdot 7$ & 740 & 1011 \\
\hline & Conglomerate & 4.5 & 640 & 833 \\
\hline
\end{tabular}

Interestingly, if we were to double the rock mass stiffness values used for the foundation design of the Burj Khalifa, after Poulos (2008), such that the predicted settlement equals the measured values; the revised stiffnesses would align with the lower bound relationship proposed above. This constitutes a good validation of the proposed relationship from a reliable, published, external source of information.

Conversely, the back-analysed stiffnesses presented in this paper yielded much higher values of rock mass stiffness, generally well in excess of $1000 \mathrm{MPa}$. These compare well with the outcome of the work carried out by Alzaylaie (2017). The work carried out by Alzaylaie was presented multiple times at international conferences by Professor Dr.-Ing. Rolf Katzenbach with nearly $90 \%$ of backanalysed rock mass stiffness values between 900 and $7000 \mathrm{MPa}$.

\section{Skin friction and UCS}

Table 8 summarises the measured and back-analysed skin friction values for each of the 14 selected preliminary pile tests. These results are also illustrated in Figures 21 and 22, in the context of the Dubai industry practice and other publications.

The information in the following section presents the plots of the analyses' results with associated correlations. Two different correlations are proposed; one is based on the measured skin friction resistances from the PTP results. The second correlation is based on the back-analysed skin frictions which rely on the methodology proposed in the section headed 'Available site investigation data and parameter derivation procedure' to derive Mohr-Coulomb shear strength parameters from rock parameters. The ultimate skin friction to UCS correlations proposed in this section are limited to the UCS range of 0 to $6 \mathrm{MPa}$.

\section{Measured skin friction to UCS correlation based on the pile test results}

Figure 21 illustrates the maximum mobilised skin friction values mobilised during the testing of the 14 PTPs selected for backanalysis. In accordance with the explanation provided in the section headed 'Mobilised skin frictions during testing and identification of outliers', only skin friction values for rock units located nearest to the load cell assembly were selected. All backanalysed values are higher than predictions from the relationships proposed by Horvath and Kenney (1979) and Horvath et al. (1983). The data seem to be consistently between the smooth and

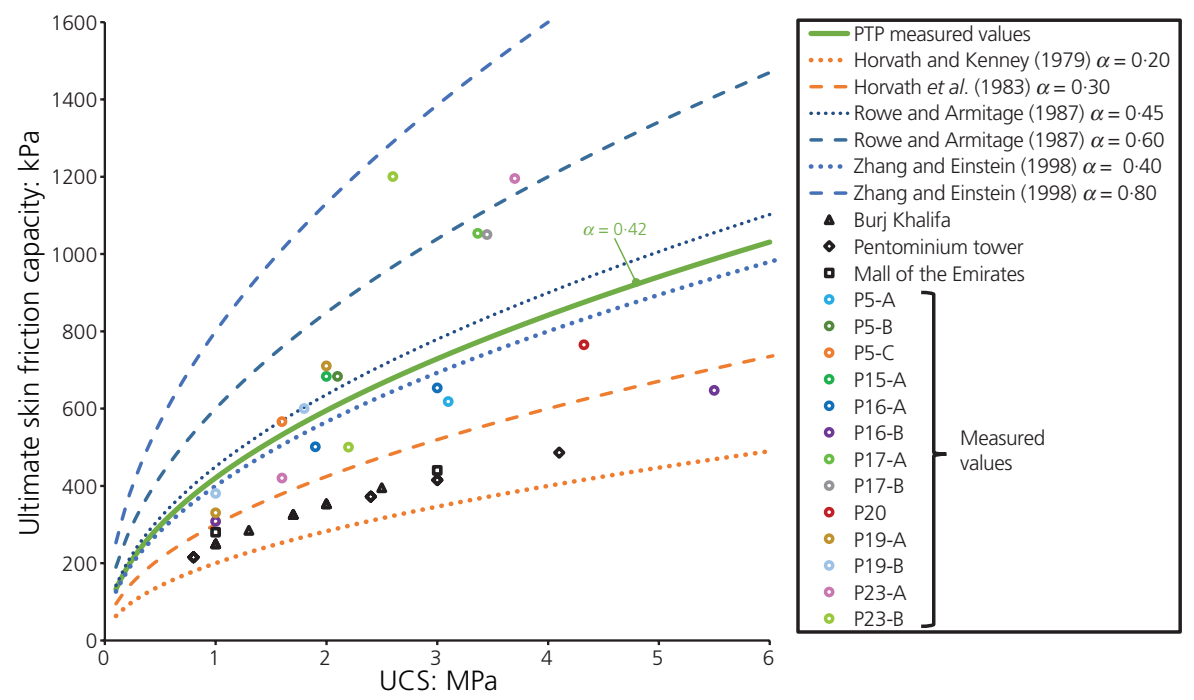

Figure 21. Measured skin friction values 


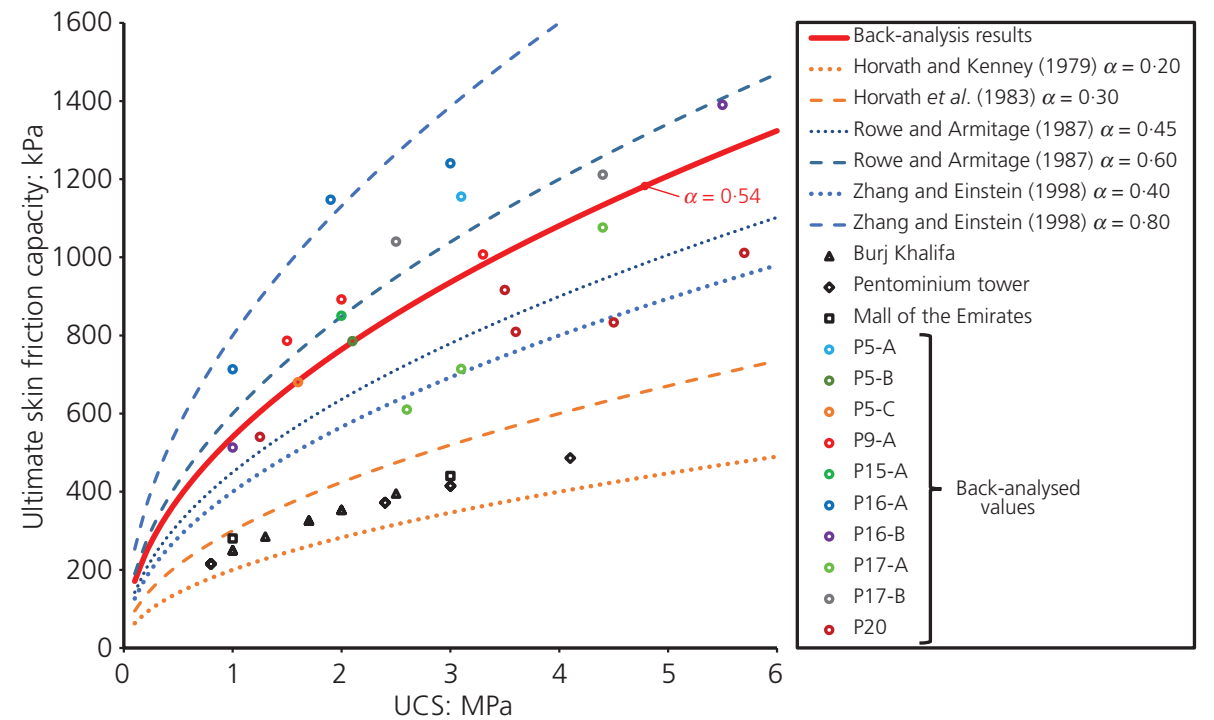

Figure 22. Back-analysed skin friction values

rough relationships proposed by Zhang and Einstein (1998). Using a power regression interpolation, the following correlation was derived from the back-analysed data

\section{5. $\tau_{\mathrm{m}}=0.42 \times \sqrt{\mathrm{UCS}}$}

In the authors' opinion, the preceding correlation is conservative, as most PTPs did not reach geotechnical failure.

\section{Ultimate skin friction to UCS correlation based on the back-analysis results}

Figure 22 illustrates the back-analysed skin friction values for the corresponding characteristic rock UCS values for all 14 backanalysed PTPs. Note that more than 14 points have been plotted, which signifies that several tests had more than one rock unit, with different UCS values. Each rock unit was back-analysed independently as explained in the section headed 'Back-analysis'. All back-analysed values are higher than predictions from the relationships proposed by Horvath and Kenney (1979) and Horvath et al. (1983). The data seem to be consistently between the smooth and rough relationships proposed by Zhang and Einstein (1998). Using a power regression interpolation, the following correlation was derived from the back-analysed data

\section{6. $\tau_{\mathrm{ult}}=0.54 \times \sqrt{\mathrm{UCS}}$}

In the authors' opinion, the preceding correlation is likely to be conservative; still, as for most PTPs back-analysed, geotechnical failure was not reached during the test, and, hence, only a lower bound estimate of the ultimate skin friction resistance was possible.

\section{Mobilised end-bearing resistance}

From the data pool of the preliminary test results available, 11 presented and interpreted the plot of the mobilised end-bearing resistance as a function of movement. To these results, another few preliminary pile load test results which did not qualify for back-analysis (due to lack of data) were added. This information is illustrated in Figure 23, which shows a plot of the measured mobilised end-bearing resistance as a function of settlement. This shows that for an example service settlement of $10 \mathrm{~mm}$ (well within what is tolerable by tall buildings during their construction), unit end-bearing resistance of $1250-8000 \mathrm{kPa}$ may be mobilised. For a $1.5 \mathrm{~m}$ dia. pile, this relates to an allowable end-bearing resistance of 2210-14 $140 \mathrm{MN}$, which would help greatly reduce the pile's length if considered in design.

This is a clear indication that end-bearing resistance has been mobilised by foundation piles constructed in Dubai; hence, it is worth considering to achieve a more economical foundation design.

Approximately half of the results presented measured end bearing over small values of settlement. This is because the tests were not sufficiently loaded to mobilise ultimate skin resistance over the bottom part of the pile. This is because the preliminary pile was designed using an over-conservative skin friction to UCS relationship.

\section{Conclusions and recommendations}

The research presented in this paper provides an industry-wide review of the Dubai piling industry design practices with results that will enable meaningful improvements, once supported by all local authorities. This section presents the main conclusions of this paper, by topic, as well as a general recommendation on how the industry should coordinate efforts to improve the status quo. 


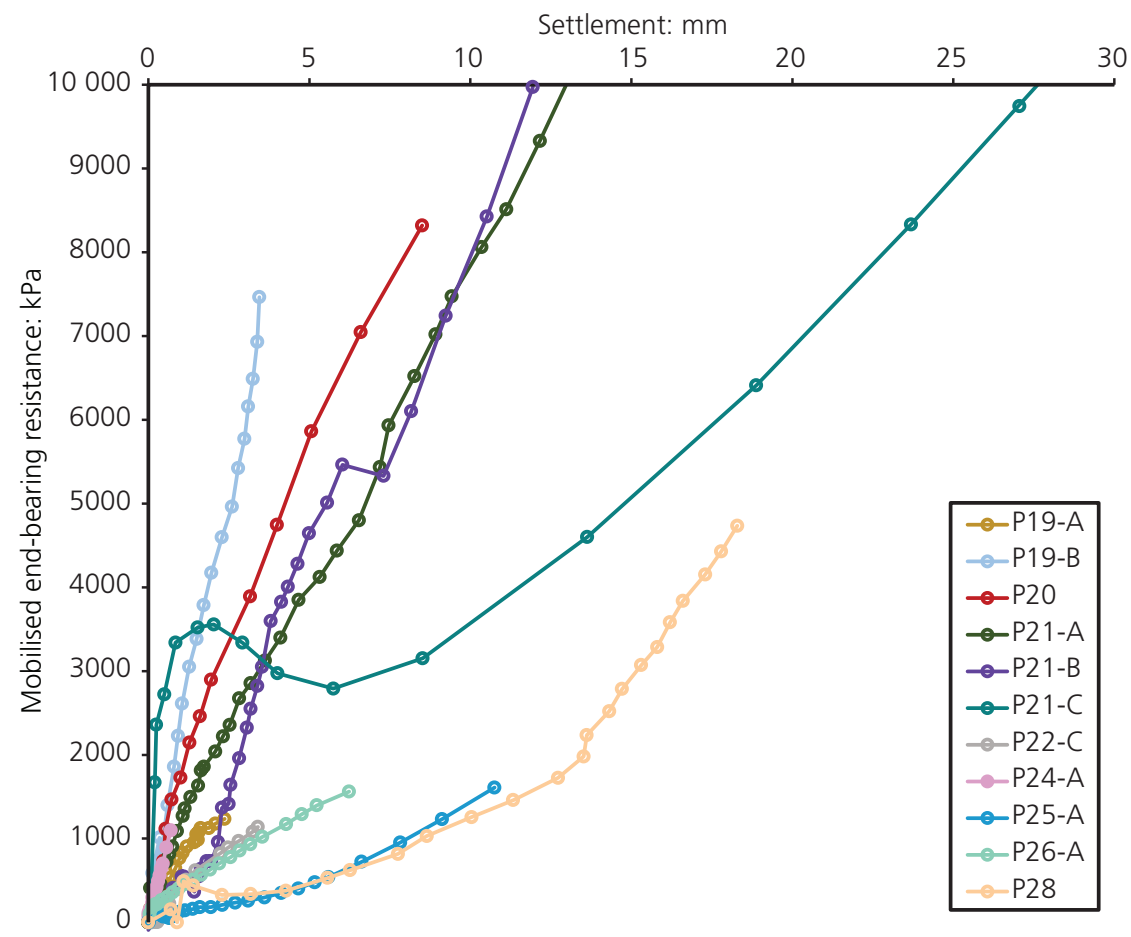

Figure 23. Mobilised end-bearing resistance

\section{Ultimate skin friction to UCS relationship}

It was proven that the relationships presented in Table 9 are more representative of the real skin friction that may be generated by a rock mass with a given unconfined shear strength. In the authors' opinion, such relationships may be used on projects under the conditions summarised in Table 9. The use of such relationships on projects relies on the assumption that constructed working piles will meet the requirements of international standards for construction quality such that the full pile-rock skin friction may be developed during the design life of the pile foundation.

\section{PTP recommendations}

Where possible, the UCS to ultimate skin friction design relationship to be used on a project should be defined and optimised using the results and back-analysis of preliminary pile(s) tested to geotechnical failure (as defined in the section headed 'Definition of geotechnical failure'). When designing a PTP, the goal should be to mobilise sufficient geotechnical behaviour to interpret ultimate geotechnical resistance rather than verify a conservative empirical relationship. The authors recommend that PTPs be designed using an optimistic UCS to ultimate skin friction relationship, perhaps within the following range

\section{7. $\tau_{\mathrm{PTP}}=[1 \cdot 0$ to $1 \cdot 2] \times \sqrt{\mathrm{UCS}}$}

In the typical rock sockets tested in Dubai, the maximum test load of the bidirectional loading assembly may be determined by the pile diameter. Then, the designer should limit the length of the test pile to ensure that the optimistic estimate of ultimate skin friction can be reached. Testing a reduced length pile compared to the intended final design length is acceptable so long that size differences between test and working piles are not subject to scaling effects and that the test pile is located in the same material as the working piles.

\section{End bearing}

The notion that end-bearing resistance should systematically be ignored without a valid engineering reason is conservative. Endbearing resistance should be taken into account, where applicable, in the design of pile foundations.

Based on the measurements presented in this paper, in the rock units encountered in Dubai, it would take a large amount of settlement to mobilise sufficient end-bearing resistance so that

Table 9. Measured and back-analysed skin frictions

\begin{tabular}{|c|c|c|}
\hline Description & Relationship & When to use \\
\hline $\begin{array}{l}\text { Measured, robust } \\
\text { Back-analysed }\end{array}$ & $\begin{array}{l}\tau_{\mathrm{m}}=0.42 \times \mathrm{UCS}^{1 / 2} \\
\tau_{\mathrm{ult}}=0.54 \times \mathrm{UCS}^{1 / 2}\end{array}$ & $\begin{array}{l}\text { This relationship is proven and robust and may be used as default on Dubai projects. } \\
\text { Before implementation, this relationship should be proven through PTP(s) loaded to geotechnical } \\
\text { failure as defined in the section headed 'Definition of geotechnical failure'. }\end{array}$ \\
\hline
\end{tabular}


asymptotic behaviour can be interpreted. This means that the true ultimate end-bearing resistance of pile foundations in those material is likely to be much higher than what is sometimes assumed in design calculations. By the same token, calculating the allowable service load attributable to the end bearing by dividing the ultimate resistance by a set factor of safety may not achieve the required service settlement limit. Instead, it seems more appropriate to allow for the end-bearing resistance mobilised at the service settlement as measured in a project-specific PTP.

Carrying out PTP(s) such that sufficient geotechnical behaviour is captured in the pile's load-deflection curve would enable determining the amount of end-bearing resistance that may be mobilised at service settlement for the piles, ensuring that the amount considered in design is both safe and economical.

\section{Rock mass stiffness to UCS relationship}

The back-analyses carried out and presented in this paper have enabled capturing the envelope of extremum relationships of rock mass stiffness as a function of UCS. A robust lower bound has been established and assessed against the available published information on Burj Khalifa. Also, an upper relationship was derived and tallies well with the work by Alzaylaie (2017) in his $\mathrm{PhD}$ thesis entitled Stiffness and Strength of Dubai Sedimentary Rock, which captured all the projects constructed in the Business Bay District at the time of writing this paper. This means that the upper relationship is likely to be valid for some locations in Dubai, but before it is used in design, it ought to be validated with project-specific pile load test data. Both recommendations are summarised in Table 10.

\section{Pile design factor of safety}

The choice of factor of safety should depend on the relative uncertainty of the pile design on a given project. Such uncertainty is inherently related to the maturity of the industry as well as the number of preliminary and working load test that will be carried out on the project. For instance, projects carrying preliminary pile test(s) and working load test should be allowed to use reduced factors of safety on pile foundation design, compared with project not testing their foundations. It is recommended that the provisions made by BS EN 8004:2015 for bored cast-in-place piles on this topic be implemented in Dubai as they promote the healthy, good practice of developers investing in reducing geotechnical risk on their projects to recuperate savings on the construction costs.

\section{How can industry practices in the Emirate be improved?}

From the study conducted and presented in this paper, it is evident that the Dubai piling industry may routinely construct over-conservative designs. In some cases, this is to balance poor construction quality. This means that a large amount of concrete and steel reinforcement could be routinely wasted on Dubai projects. The authors urge colleagues from the industry (consultants, site investigation and piling contractors and local authorities) to join their efforts and improve the current status quo. We must all act together in order to stop the current systematic over-engineering of pile foundations for buildings. This must be done in conjunction with the implementation of high construction quality standards and without compromising safety.

It is recognised that this cannot happen by simply changing the default UCS to ultimate skin friction used in design and that fundamental changes to the way the piling industry operates are required. Foundation design for buildings should be carried out by a (specialist) geotechnical engineer who has detailed knowledge of the dimensions, stiffness and loads of the building to be constructed. Generic 'fit-all' foundation design as often proposed in reports produced by site investigation contractors are not recommended. The specialist geotechnical designers ought to be paired with an experienced and competent piling contractor to capitalise on what resistance the ground can provide when piles are installed with the optimum methodology.

All Dubai local authorities should follow the example set by the Dubai Creative Clusters Authority and employ experienced geotechnical engineers/specialists in their building approval departments. This would vastly help coordinate and streamline geotechnical guidelines between authority bodies and by the same token would reduce the geotechnical risks to projects.

The authors invite their colleagues from the industry to pursue the reduction of overconservatism in pile design in Dubai and continue this research. The design and construction of PTPs to geotechnical failure is paramount to establishing a reliable relationship between UCS and ultimate skin friction for bored piles in Dubai.

Humanity is at an age of development where sustainable thinking and innovation have surpassed good engineering practice and have become a social duty. Over-engineering out of lack of time or will is no longer socially acceptable; everybody is responsible for the planet that will be left to future generations.

\section{Recommendations for future work}

One of the biggest shortfalls of the proprietary database used for this paper is the lack of pile load test results having reached geotechnical failure. A great continuation of the work presented in this paper would be to either gather or produce pile load test

Table 10. Back-analysed rock mass stiffness

$\begin{array}{lll}\text { Description } & \text { Relationship } & \text { When to use } \\ \text { Robust lower bound } & E_{\mathrm{LB}}=430 \times \mathrm{UCS} & \begin{array}{l}\text { This relationship is proven and robust and may be used as default on Dubai projects. } \\ \text { Upper bound }\end{array} E_{\mathrm{UB}}=1720 \times \mathrm{UCS} \text { Before implementation, this relationship should be proven through pile testing. This may be done } \\ \text { through PTP(s) loaded to geotechnical failure or through working pile load tests. }\end{array}$


results for pile having been brought to geotechnical failure such that the UCS to ultimate skin friction and to stiffness relationships for bored piles in Dubai are defined more accurately.

Clear evidence of large end-bearing resistance being mobilised during pile tests is presented in this paper, and it would beneficial to pursue work with more test results such that a UCS to end bearing relationship may be derived and proposed for Dubai rocks. This would greatly help the routine practice of the local industry in ignoring end-bearing contributions from its pile foundations.

\section{REFERENCES}

Aashto (American Association of State Highway and Transportation Officials) (2012) Foundations. In AASHTO LRFD Bridge Design Specifications, Customary U.S. Units, 4th edn. Aashto Washington, DC, USA.

Abbs AF and Needham AD (1985) Grouted piles in weak carbonate rocks. Proceedings of the Offshore Technology Conference, Houston, TX, USA, paper OTC-4852.

Alrifai L (2007) Rock socket piles at Mall of the Emirates, Dubai. Proceedings of the Institution of Civil Engineers - Geotechnical Engineering 160(2): 105-120, https://doi.org/10.1680/geng.2007.160. 2.105 .

Alzaylaie M (2017) Stiffness and Strength of Dubai Sedimentary Rock. PhD thesis, Technische Universität Darmstadt, Darmstadt Germany.

ASTM (2007) D 1143/D 1143M-07: Standard test methods for deep foundations under static axial compressive load. ASTM International, West Conshohocken, PA, USA

Bell A and Robinson C (2012) Single piles. In ICE Manual of Geotechnical Engineering (Burland J, Chapman T, Skinner H and Brown M (eds)). ICE Publishing, London, UK, vol. II, pp. 803-821.

BGS (British Geological Survey) (2012) Dubai, Sharjah and Sir Bu N'Air Geological Map. 1:100 000 Series, 100-5. BGS, Nottingham, UK.

Bieniawski ZT (1989) Engineering Rock Mass Classifications: a Complete Manual for Engineers and Geologists in Mining, Civil, and Petroleum Engineering. Wiley, Hoboken, NJ, USA.

Brown AD, Turner JP and Castelli RJ (2010) Drilled Shafts: Construction Procedures and LRFD Design Methods. National Highway Institute, U.S. Department of Transportation Federal Highway Administration, Washington, USA, Report no. FHWA NHI-10-016.

BSI (1999) BS 5930:1999+A2:2010: Code of practice for site investigations. BSI, London, UK

BSI (2015) BS 8004:2015: Code of practice for foundations. BSI, London, UK.

Carter JP and Kulhawy FH (1987) Analysis and Design of Foundations Socketed into Rock. Geotechnical Engineering Group, Cornell University, Ithaca, NY, USA, Res. Rep. 1493-4.

Carter TG, Diederichs MS and Carvalho JL (2008) Application of modified Hoek-Brown transition relationships for assessing strength and post-yield behaviour at both ends of the rock competence scale. Journal of the Southern African Institute of Mining and Metallurgy 108(6): 325-337.

Charif KH, Najjar SS and Sadek S (2010) Side friction along drilled shafts in weak carbonate rocks. In The Art of Foundation Engineering Practice Congress 2010 (Hussein MH, Anderson JB and Camp WM (eds)). American Society of Civil Engineers, Reston, VA, USA, pp. 190-204, https://doi.org/10.1061/41093(372)5.

СTBUH (Council on Tall Buildings and Urban Habitat) (2018) http://www. ctbuh.org (accessed 24/08/2018)

England M (2003) Bi-directional static load testing - state of the art. Proceedings of the 4th Geotechnical Seminar on Deep Foundations on Bored and Augered Piles, Ghent, Belgium, pp. 309-313.

England M (2008) Review of methods of analysis of test results from bidirectional static load tests. Deep Foundations on Bored and Auger Piles, BAP V, Ghent, Belgium, pp. 235-239.
Gannon JA, Masterton GGT, Wallace WA and Muir Wood D (1999) Piled Foundations in Weak Rock. Construction Industry Research \& Information Association, London, UK.

Haberfield C (2013) Practical experience with piled raft design for tall buildings. Proceedings of the 18th International Conference on Soil Mechanics and Geotechnical Engineering, Paris, France, paper no. 2623.

Hoek E and Brown ET (1997) Practical estimates of rock mass strength. International Journal of Rock Mechanics and Mining Sciences 34(8): 1165-1186, https://doi.org/10.1016/S1365-1609(97)80069-X.

Hoek E, Kaiser PK and Bawden WF (1995) Support of Underground Excavations in Hard Rock. Taylor \& Francis, Abingdon, UK.

Hoek E, Carranza-Torres C and Corkum B (2002) Hoek-Brown failure criterion - 2002 edition. In NARMS-TAC 2002: Mining and Tunnelling Innovation and Opportunity: Proceedings of the 5th North American Rock Mechanics Society Meeting and 17th Tunnelling Association of Canada Conference (Hammah R, Bawden W, Curran J and Telesnicki M (eds)). University of Toronto Press, Toronto, ON, Canada, vol. 1, pp. 267-273.

Horvath RG (1978) Field Load Test Data on Concrete-to-Rock Bond Strength for Drilled Pier Foundations. University of Toronto, Toronto, ON, Canada, Publication 78-07.

Horvath RG and Kenney TC (1979) Shaft resistance of rock socketed drilled piers. In Proceedings of the Symposium on Deep Foundations (Fuller FM (ed.)). American Society of Civil Engineers, New York, NY, USA, pp. 182-214.

Horvath RG, Kenney TC and Kozicki P (1983) Methods of improving the performance of drilled piers in weak rock. Canadian Geotechnical Journal 20(4): 758-772, https://doi.org/10.1139/t83-081.

Ibrahim K, Bunce G and Murrells C (2009) Foundation design for the Pentominium tower in Dubai, UAE. Proceedings of the Institution of Civil Engineers - Civil Engineering 162(6): 25-33, https://doi.org/10. 1680/cien.2009.162.6.25.

ICE (Institution of Civil Engineers) (2007) ICE Specification for Piling and Embedded Retaining Walls, 2nd edn. ICE, London, UK.

ICE (2016) ICE Specification for Piling and Embedded Retaining Walls, 3rd edn. ICE, London, UK.

Johnston IW (1991) Geomechanics and the emergence of soft rock technology. Australian Geomechanics 21: 3-25.

Karagkounis N, Latapie B, Sayers K and Mulinti SR (2016) Geology and geotechnical evaluation of Doha rock formations. Geotechnical Research 3(3): 119-136, https://doi.org/10.1680/jgere.16.00010.

Kulhawy FH and Phoon KK (1993) Drilled shaft side resistance in clay soil to rock. In Proceedings of the Conference on Design and Performance of Deep Foundations: Piles and Piers in Soil and Soft Rock (Nelson PP, Smith TD and Clukey EC (eds)). American Society of Civil Engineers, New York, NY, USA, Geotechnical Special Publication 38, pp. 72-183.

Latapie B and Lochaden AL (2015) Range of confining pressures for the Hoek-Brown criterion. Geotechnical Research 2(4): 148-154, https://doi.org/10.1680/jgere.15.00008.

Macklin S, Richard E, Jason M, Farrant A and Lorenti L (2012) The engineering geological characterisation of the Barzaman Formation, with reference to Coastal Dubai, UAE. Bulletin of Engineering Geology and Environment 71(1): 1-19, https://doi.org/10.1007/ s10064-011-0369-4.

Meigh AC and Wolski W (1979) Design parameters for weak rock. In Proceedings of 7th European Conference on Soil Mechanics and Foundation Engineering. British Geotechnical Society, London, UK, vol. 5, pp. 59-79.

O'Neill MW and Reese LC (1999) Drilled Shafts: Construction Procedures and Design Methods. Federal Highway Administration, Washington, DC, USA, Report No. FHWA-IF-99-025

Osterberg JO (1989) New device for load testing driven piles and drilled shafts separates friction and end bearing. Proceedings: International Conference on Piling and Deep Foundations, London, UK. 
Geotechnical Research

Volume 6 Issue GR2
A review of piling industry practices in

Dubai, UAE: proposed UCS-based

correlations

Latapie, Albelda, Abou Samra, Alzaylaie and Sumputh
Osterberg JO (1998) The Osterberg load test method for bored and driven piles - the first ten years. Proceedings of the 7th International Conference \& Exhibition on Piling and Deep Foundations, Deep Foundations Institute, Vienna, Austria.

Poulos HG and Bunce G (2008) Foundation design for the Burj Dubai the world's tallest building. Proceedings of the 6th International Conference on Case Histories in Geotechnical Engineering, Arlington, VA, USA. See http://scholarsmine.mst.edu/icchge/6icchge/session_01/14 (accessed 28/08/2018).

Poulos HG and Davids AJ (2005) Foundation design for the emirates twin towers, Dubai. Canadian Geotechnical Journal 42(3): 716-730, https://doi.org/10.1139/t05-004.

Reese LC and O'Neill MW (1988) Drilled Shafts: Construction Procedures and Design Methods. US Department of Transportation, Dallas, TX, USA, FHWA-HI-88-042.

Rosenberg P and Journeaux NL (1976) Friction and end bearing tests on bedrock for high capacity socket design. Canadian Geotechnical Journal 13(3): 324-333, https://doi.org/10.1139/t76-033.
Rowe RK (1987) A new design method for drilled piers in soft rock: implications relating to three published case histories. Proceedings of the 6th ISRM Congress, 30 August-3 September, Montreal, QC, Canada, pp. 497-502.

Rowe RK and Armitage HH (1987) Theoretical solution for axial deformation of drilled shaft. Canadian Geotechnical Journal 24(1): 114-125, https://doi.org/10.1139/t87-010.

Sharif EY and Ahmed MJ (2010) Engineering Geology of Dubai. Arab Centre for Engineering Studies (ACES), Amman, Jordan.

Williams AF and Pells PJN (1981) Side resistance rock sockets in sandstone, mudstone, and shale. Canadian Geotechnical Journal 18(4): 502-513, https://doi.org/10.1139/t81-061.

Williams AF, Donald IB and Chiu HK (1980) Stress distributions in rock socketed piles. Proceedings, International Conference on Structural Foundations on Rock, Sydney, Australia, pp. 317-326.

Zhang L and Einstein HH (1998) End bearing capacity of drilled shafts in rock. Journal of Geotechnical and Geoenvironmental Engineering 124(7): 574-584, https://doi.org/10.1061/(ASCE)1090-0241(1998)124:7(574).

\section{How can you contribute?}

To discuss this paper, please submit up to 500 words to the editor at journals@ice.org.uk. Your contribution will be forwarded to the author(s) for a reply and, if considered appropriate by the editorial board, it will be published as a discussion in a future issue of the journal. 